Provided for non-commercial research and education use. Not for reproduction, distribution or commercial use.

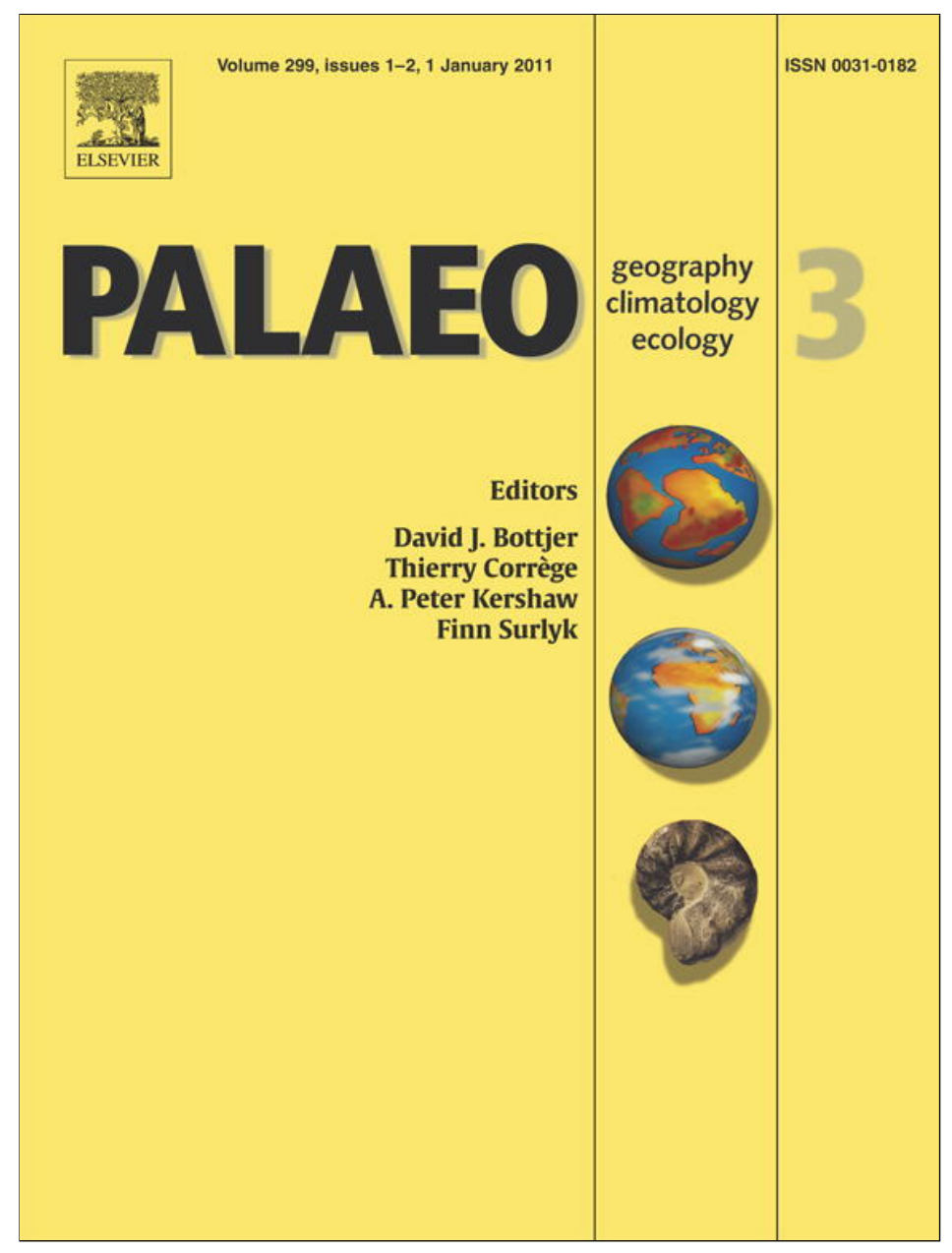

This article appeared in a journal published by Elsevier. The attached copy is furnished to the author for internal non-commercial research and education use, including for instruction at the authors institution and sharing with colleagues.

Other uses, including reproduction and distribution, or selling or licensing copies, or posting to personal, institutional or third party websites are prohibited.

In most cases authors are permitted to post their version of the article (e.g. in Word or Tex form) to their personal website or institutional repository. Authors requiring further information regarding Elsevier's archiving and manuscript policies are encouraged to visit:

http://www.elsevier.com/copyright 


\title{
Petrography and high-resolution geochemical records of Lower Jurassic manganese-rich deposits from Monte Mangart, Julian Alps
}

\author{
N. Sabatino ${ }^{\text {a }}$, R. Neri ${ }^{\text {a,* }}$, A. Bellanca ${ }^{\text {a }}$, H.C. Jenkyns ${ }^{\text {b }}$, D. Masetti ${ }^{\text {c }}$, G. Scopelliti ${ }^{\text {a }}$ \\ a Dipartimento di Chimica e Fisica della Terra (CFTA), Università di Palermo, Via Archirafi 36, 90123 Palermo, Italy \\ ${ }^{\mathrm{b}}$ Department of Earth Sciences, University of Oxford, Parks Road, Oxford OX1 3PR, UK \\ c Dipartimento di Scienze della Terra, Università di Ferrara, Via Saragat 1, 44100, Ferrara, Italy
}

\section{A R T I C L E I N F O}

\section{Article history:}

Received 15 October 2009

Received in revised form 30 September 2010

Accepted 29 October 2010

Available online 5 November 2010

\section{Keywords:}

Early Toarcian

Mn-bearing deposits

Anoxic Event

Stable isotope stratigraphy

Rare earth elements

\begin{abstract}
A B S T R A C T
Deposits with unusually high Mn contents sampled at Monte Mangart in the Julian Alps include organic-rich marlstone and black shale with interbedded manganoan and siliceous limestone, which were deposited during the early Toarcian Oceanic Anoxic Event. Mn enrichment during that period has been related to global sea-level change coincident with increasing subsidence rate. The formation of Fe-Mn nodules, marking a hardground at the base of the Monte Mangart section, seems to be triggered by release of Mn from remote hydrothermal vents into a region of relatively elevated submarine topography where oxidizing conditions prevailed. However, very high Mn contents in carbonate phases above the hardground imply an additional diagenetic source of this element in the lower part of this section. The whole stratigraphic sequence (ca $30 \mathrm{~m})$ displays a transition from Mn-rich (up to 8.8\%) sediments, in the lower part, to Mn-poor (less than 1.8\%) sediments in the middle and upper parts. The drastic decrease in Mn content's up-section is accompanied by a clear decrease in the mean size of pyrite framboids, indicating more intense anoxia/euxinia in the water column. In the presence of $\mathrm{Mn}^{2+}$, conditions of high alkalinity induced precipitation of Mn carbonates during early diagenetic processes. Negative $\delta^{13} \mathrm{C}_{\text {carb }}$ values coincident with high Mn contents indicate involvement of organic matter in the mineralization process. The striking similarity of $\mathrm{Ce} / \mathrm{Ce}^{*}$ and $\mathrm{Mn}$ profiles demonstrates that, consistent with redox-chemistry of $\mathrm{Mn}$ and $\mathrm{Ce}$ under anoxic conditions, $\mathrm{Ce}^{3+}$ and $\mathrm{Mn}^{2+}$ were mobilized and released into pore water where precipitation of Mn carbonates occurred.
\end{abstract}

(c) 2010 Elsevier B.V. All rights reserved.

\section{Introduction}

Lower Toarcian strata of the western Tethys are characterized by widespread occurrence of manganese-bearing deposits. Sediments in anoxic marine environments are commonly depleted in manganese because low Eh values favour the stability of $\mathrm{Mn}^{2+}$ ions in aqueous solutions (Force and Cannon, 1988). However, Mn-rich $\left(\mathrm{Mn}^{2+}\right)$ carbonates stratigraphically associated with Jurassic black shales have been recognized in basinal pelagic deposits from Austria, Germany, Switzerland, Slovakia, Italy, and Hungary (Bellanca et al., 1999; Corbin et al., 2000; Ebli et al., 1998; Jenkyns, 1988; Jenkyns et al., 1991; Polgári et al., 1991, 2004; Rantitsch et al., 2003; Vetö et al., 1997). Ferromanganese oxyhydroxide crusts and nodules $\left(\mathrm{Mn}^{4+}\right)$ formed on topographic highs (seamounts) in relatively shallow waters are also characteristic of the Jurassic Tethys (Cronan et al., 1991; Di Stefano et al., 2002; Jenkyns, 1970, 1971, 1977). Several authors (i.e. Corbin et al., 2000; Jach and Dudek, 2005) linked the elevated concentrations of Mn in Jurassic sediments of the western

\footnotetext{
* Corresponding author.

E-mail address: neri@unipa.it (R. Neri).
}

Tethys to increasing submarine hydrothermal activity during progressive rifting of the Tethyan passive continental margin; in addition, Jenkyns et al. (1991) suggested a possible continental derivation of Mn transported through the oxygen minimum zone across the Tethyan continental margin.

The Monte Mangart section discussed in this paper contains well exposed organic-rich marlstone and black shale that are stratigraphically associated with both manganoan carbonates and ferromanganese oxyhydroxide nodules. Based on radiolarian fauna, Goričan et al. (2003) dated the studied interval as early to middle Toarcian in age. Comparison of the organic carbon-isotope record from Monte Mangart with records of coeval sections of the Tethyan and Boreal realms confirmed that the black shale horizon can be ascribed to the upper part of the Tethyan tenuicostatum Ammonite Zone or to the lower part of the boreal falciferum ammonite Zone (Sabatino et al., 2009).

This work presents a multi-proxy study of lower Toarcian strata that includes new records of carbon and oxygen isotopes from bulk carbonate sediments combined with mineralogical, petrographical and geochemical data. The aim of the study was 1) to document changes in abundance of $\mathrm{Mn}$ in response to the early Toarcian Oceanic Anoxic Event (T-OAE) in the western Tethys and 2) to contribute to 
the understanding of $\mathrm{Mn}$ mineralization during early diagenetic processes in dysaerobic to anoxic environments.

\section{Geological setting}

The Monte Mangart area is located in the Julian Alps along the Italian-Slovenian border. The Julian Alps belong to the Julian Nappe, which forms part of the Southern Alps together with the underlying Tolmin Nappe (Placer, 1999). During the Jurassic, the Julian Alps comprised part of the southern Tethyan passive continental margin recording the Late Triassic-Early Jurassic rifting that led to the development of two juxtaposed Jurassic palaeogeographic units: the Julian High and the Slovenian Basin (Fig. 1). The Julian High palaeogeographic unit was considered by Buser (1996) to have formed from a carbonate platform that drowned in the Early Jurassic probably around Sinemurian/Pliensbachian boundary time. This unit was characterized by irregular seafloor topography because the drowned platform was dissected into differentially subsided blocks. During the Jurassic, some of these blocks formed isolated seamounts while other blocks became part of the deeper Slovenian Basin that received gravity-displaced sediments from an adjacent shallow-water carbonate platform, as was the case with Monte Mangart (Cousin, 1981; Šmuc and Goričan, 2005).

The studied section is well exposed along the Slovenian-Italian border (Fig. 1) on the saddle between Travnik and Mali Mangart (Šmuc and Goričan, 2005). Here, the stratigraphic succession has been subdivided by Goričan et al. (2003) into four distinct lithostratigraphic units (Fig. 2B). At the base, Unit 1 consists of HettangianSinemurian platform carbonates that submerged near the time of the Sinemurian/Pliensbachian boundary. Unit 2, which consists of bioclastic wackestone and packstone with echinoderms, sponge spicules and juvenile ammonites, was deposited in a deeper environment than Unit 1, on top of the drowned platform, and is capped by a hardground with ferromanganese nodules (Fig. 2C) suggesting a reduced sedimentation rate (Jenkyns, 1970). The age of this Unit is thought to correspond approximately to the time interval that contains the Pliensbachian/Toarcian boundary (Šmuc and Goričan, 2005). Unit 3, the subject of this study, is composed of organic-rich layers that reflect the Toarcian Oceanic Anoxic Event in the Julian Basin/Plateau (Jenkyns, 1988; Jenkyns and Clayton, 1986) as suggested by the radiolarian ages of Goričan et al. (2003) and Šmuc and Goričan (2005). By the early Toarcian, the Monte Mangart area had ceased to be a topographic high and became an anoxic basin trapping fine-grained sediment. In Unit 3, organic-rich bioturbated marlstone and black shale with interbedded manganoan and siliceous limestones (Fig. 2A) represent the lateral equivalent of the black shales in the neighbouring Belluno Basin (Bellanca et al., 1999; Claps et al., 1995; Jenkyns et al., 1985; Masetti and Bianchin, 1987). The classic black shale facies characterized by millimetre-scale lamination, high TOC and low $\mathrm{CaCO}_{3}$ contents, never developed.

Thin-bedded recrystallized limestone at the top of Unit 3 reflects slow sedimentation rates as evidenced by the presence of extensive borings into a hard substrate. A stratigraphic hiatus, spanning the late Toarcian, Aalenian and early Bajocian, separates Unit 3 from Unit 4. Unit 4 is a deep-sea, Middle Jurassic oolitic turbidite fan supplied by the surrounding carbonate platforms that also filled the Belluno Basin (Bosellini et al., 1981).

\section{Methods}

A total of 171 samples were collected over a 29 m-thick interval of Monte Mangart section in the Julian Alps: 162 of these were collected throughout the succession recording the T-OAE with a sampling interval varying from 10 to $30 \mathrm{~cm}$. The mineralogy of bulk-rock samples was determined by powder X-ray diffraction (XRD, Philips PW14 1373) using $\mathrm{Cu}-\mathrm{K} \alpha$ radiation filtered by a monochromator crystal, with a scanning speed of $2^{\circ} 2 \theta / \mathrm{min}$. Selected samples were investigated for textural and petrographical features using a polarizing light microscope and the Scanning Electron Microscope (SEM) LEO 440 with EDS system OXFORD ISIS Link and Si (Li) PENTAFET detector.

A total of 171 bulk-rock samples from Monte Mangart were analysed isotopically for $\delta^{13} \mathrm{C}$ and $\delta^{18} \mathrm{O}$ using a VG Isogas Prism II mass spectrometer with an on-line VG Isocarb common acid bath preparation system. Samples were cleaned with hydrogen peroxide $\left(\mathrm{H}_{2} \mathrm{O}_{2}\right)$ and acetone $\left[\left(\mathrm{CH}_{3}\right)_{2} \mathrm{CO}\right]$ and dried at $60{ }^{\circ} \mathrm{C}$ for at least $30 \mathrm{~min}$. In the instrument, they were reacted with purified phosphoric acid $\left(\mathrm{H}_{3} \mathrm{PO}_{4}\right)$ at $90{ }^{\circ} \mathrm{C}$. Calibration to PDB standard via NBS-19 was made daily using the Oxford in-house (NOCZ) Carrara marble standard. Reproducibility of replicated standards was typically better than $0.1 \%$ 。 for both $\delta^{13} \mathrm{C}$ and $\delta^{18} \mathrm{O}$.

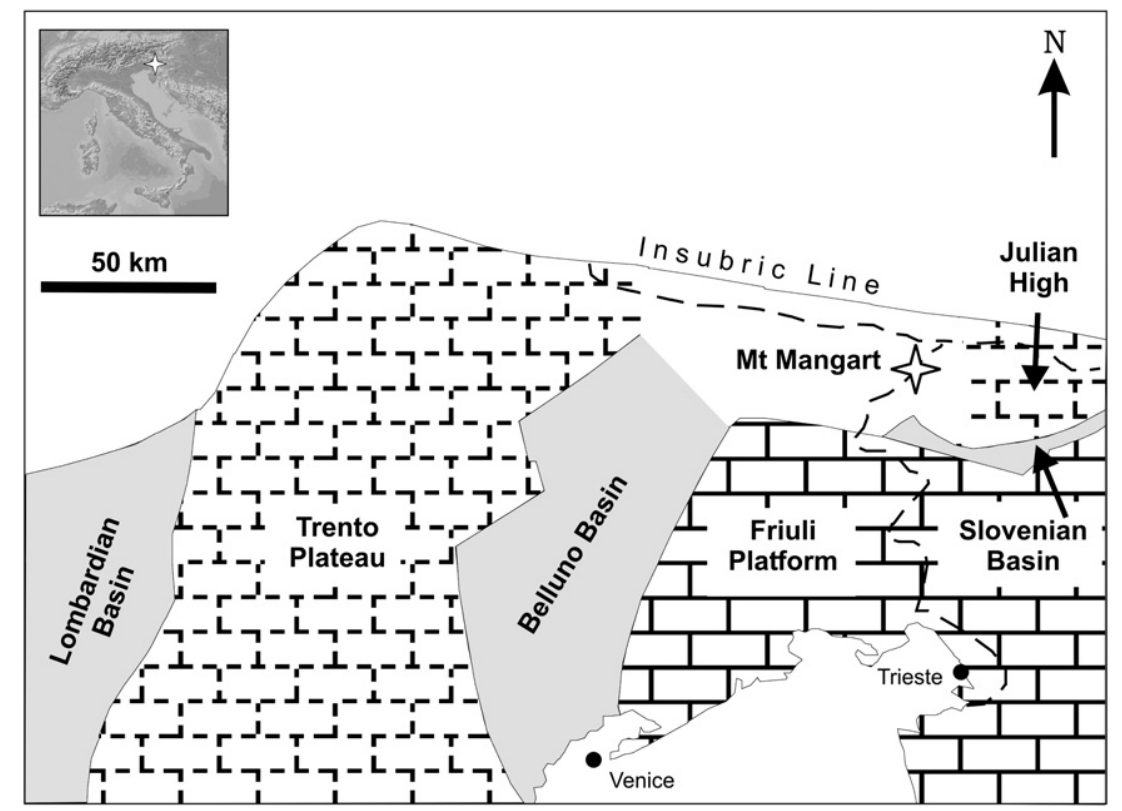

Fig. 1. Map of the palaeotectonic elements in the Southern Alps during the Early Jurassic (modified from Winterer and Bosellini, 1981) showing the location of the Monte Mangart section (star). 

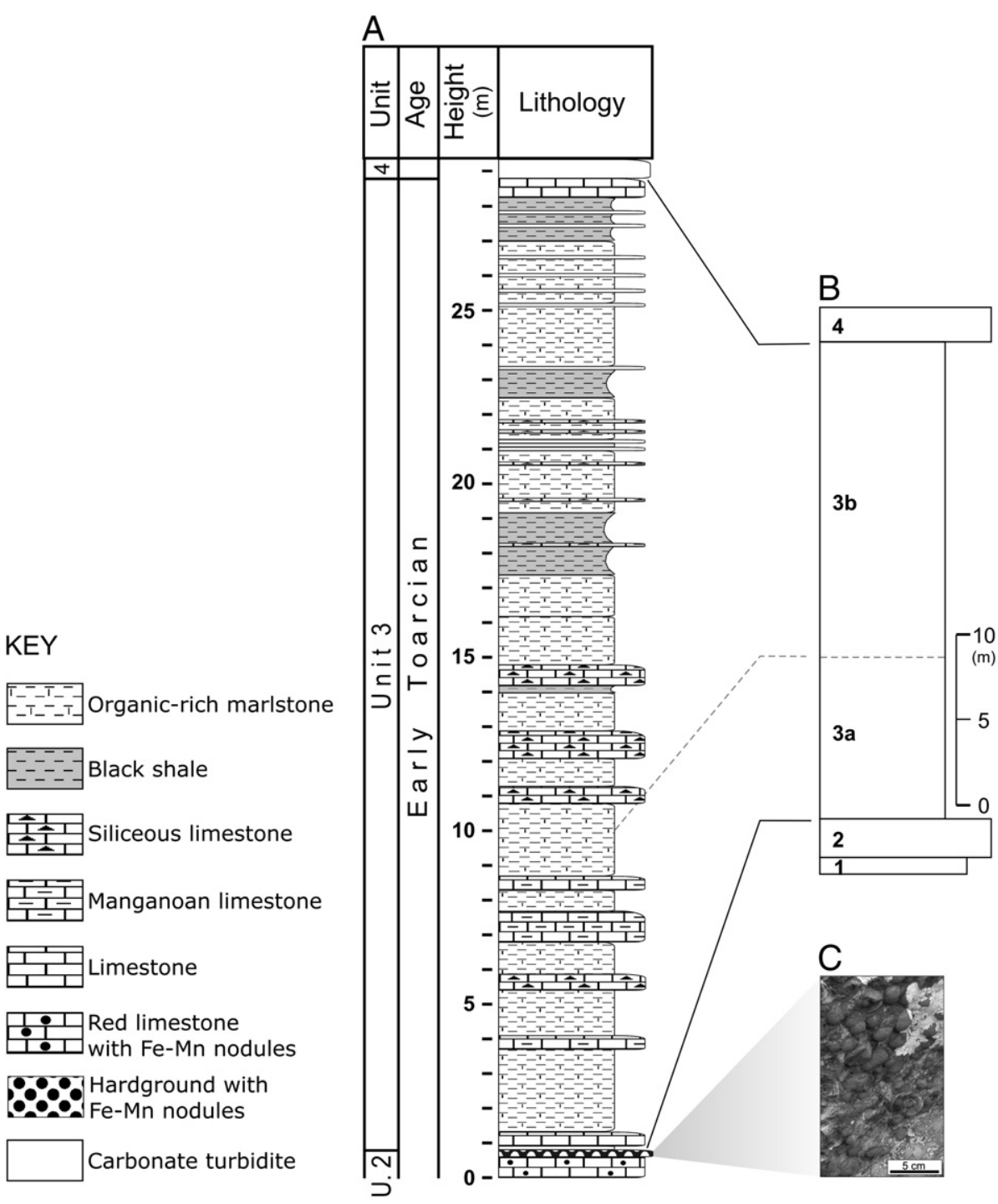

Fig. 2. (A) Lithological column of the Monte Mangart section (Unit and Age after Goričan et al., 2003). (B) Schematic stratigraphy of the studied section: $1=$ Lower Jurassic carbonate platform (Unit 1); 2 = Red limestone with Fe-Mn nodules (Unit 2); 3a = Lower Toarcian Mn-rich sediments (lower part of Unit 3); 3b=Lower Toarcian Mn-poor sediments (middle and upper parts of Unit 3); $4=$ Middle Jurassic Vajont limestone (Unit 4). (C) Field view of the hardground layer with Fe-Mn nodules.

Major-element concentrations were determined on 78 selected bulk-rock samples from Monte Mangart by X-ray fluorescence spectrometry (XRF) on pressed, boric-acid backed pellets, using a RIGAKU ZSX PRIMUS spectrometer. Data reduction was achieved using the method described by Franzini et al. (1975). Certified reference materials were used to monitor data quality. Analytical errors were below 3\% for both $\mathrm{Mn}$ and Fe. Trace element and rare earth element (REE) concentrations were determined using Induced Coupled Plasma Mass Spectroscopy (ICP-MS). A $0.5 \mathrm{~g}$ sample was digested with hydrofluoric acid, followed by a mixture of nitric and perchloric acids; following this process, controlled heating cycles were performed to bring samples to dryness. After dryness was attained, samples were brought back into solution using hydrochloric acid. Certified reference materials were used for quality control. The ICP-MS used was a Perkin Elmer Elan 6000. Detection limits were: $0.1 \mathrm{ppm}$ for Co and REE; $0.2 \mathrm{ppm}$ for $\mathrm{Cu} ; 0.5 \mathrm{ppm}$ for $\mathrm{Ni} ; 1 \mathrm{ppm}$ for $\mathrm{V}$. Comparisons among the REE were facilitated by normalizing the analytical value to an appropriate reference material such as the North American, European and Russian shale composite (Haskin and Haskin, 1966; Piper, 1974) adopted in many previous studies (i.e. Murray et al., 1991). Using the convention established by de Baar et al. (1985), the variations of $\mathrm{Ce}$ can be quantified as $\mathrm{Ce} / \mathrm{Ce}^{*}$ calculated as $\left(\mathrm{Ce}_{\mathrm{n}}\right) /(2 /$
$3 \mathrm{La}_{\mathrm{n}}+1 / 3 \mathrm{Nd}_{\mathrm{n}}$ ) where the subscript ' $\mathrm{n}$ ' refers to normalized values with respect to average shale. Total carbonate contents $\left(\mathrm{CaCO}_{3} \%\right)$ were measured by means of a classic gas-volumetric technique, as described by Hülsemann (1966). The weight percentage of total sulphur was determined by roasting samples at $1350{ }^{\circ} \mathrm{C}$ in a COULOMAT 702 ANALYSER. Precision is around $0.05 \%$.

\section{Results}

\subsection{Sedimentological and petrographical features}

\subsubsection{Ferromanganese nodules}

Ferromanganese nodules are present in a $15-30 \mathrm{~cm}$ thick interval at the base of Unit 3 (Fig. 2C). The nodules are ellipsoidal (up to $3 \mathrm{~cm}$ in maximum diameter) and commonly show a black core (size ca $2 \mathrm{~cm}$ ) and an outer rim, yellow-brown in colour, up to $1 \mathrm{~cm}$ thick. Based on SEM/EDS observations the different colours are ascribed to different mineralogy, the black core and the brown rim being dominated by $\mathrm{Mn}$ oxides and $\mathrm{Fe}$ oxyhydroxides, respectively (Fig. 3A). In the nodule core, Mn oxides are associated with dispersed calcite, Mn calcite, quartz, and clay minerals. Quartz and Mn carbonate also fill numerous cracks in the nodules (Fig. 3B). 

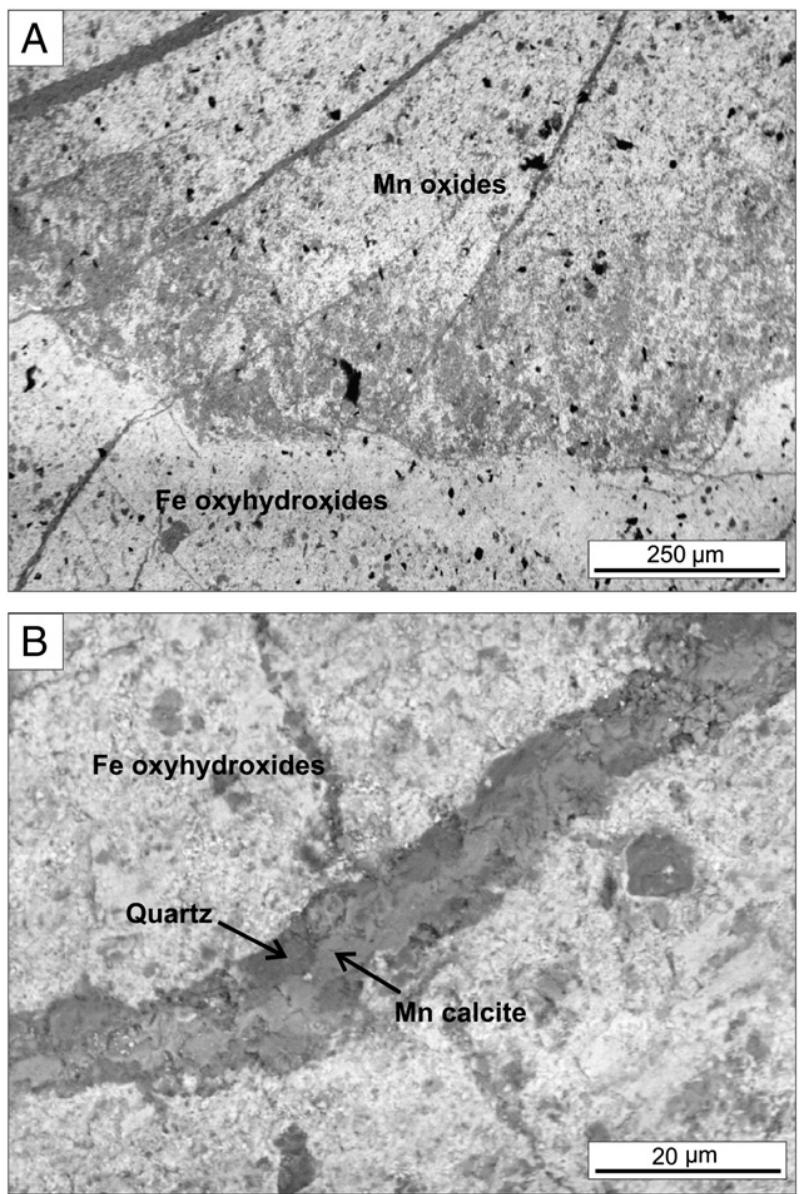

Fig. 3. SEM images. (A) Fe-Mn nodule showing concentric layers with different mineralogy: Mn oxides in the core and Fe-Mn oxyhydroxides in the outer rim. (B) Cracks in the nodule are filled with Mn carbonate and quartz.

\subsubsection{Unit 3 sediments}

The Toarcian organic carbon-rich deposits of Unit 3 are $c a 27 \mathrm{~m}$ thick and can be subdivided into two parts. In the lower part ( 0.9 to $10 \mathrm{~m}$ ), the prevalent lithology is dark marlstone, locally bioturbated, with interbedded fine-grained manganoan limestone corresponding to a higher carbonate flux that may have been supplied by a pelagic source because nearby shallow-water coeval carbonate platforms are not known from the geological record. The microfacies of the marlstone is a wackestone showing a fauna composed dominantly of radiolarians (Fig. 4A), which appear as well-preserved spherical to elliptical tests generally filled with carbonate or fan-shaped chalcedonic quartz (Fig. 4A and B). The matrix consists of micrite with variable silt/clay ratios and organic matter ( $1 \%$ mean TOC; Sabatino et al., 2009). Abundant pyrite occurs as scattered framboids (Fig. 4C and D) or filling undetermined spherical shells (Fig. 4E), while dolomite appears as rare single crystals within the rock matrix. The $\mathrm{CaCO}_{3}$ content of the lower part of Unit 3 ranges predominantly from 20 to $40 \%$ with peaks (up to $51 \%$; Table 1 ) that reflect manganoan limestone. The limestone microfacies is a radiolarian packestone (Fig. 4A) containing common phosphate debris and pyrite.

The relative high carbonate content in lower part of Unit 3 is coupled with a high Mn content (up to 8.8\%; Table 1). Radiolarian tests from the stratigraphic interval between 1.5 and $10 \mathrm{~m}$ show evidence of replacement by Mn calcite (Fig. 4A and F), which may be related to dissolution of biogenic opal (opal-A) and precipitation of $\mathrm{Mn}$ carbonates. Mn calcite, with various $\mathrm{Ca} / \mathrm{Mn}$ ratios, occurs also as cement and grain coatings (Fig. 4C and D). DRX investigations of bulk samples showed a decrease in the $\mathrm{d}_{(104)}$ basal reflection (up to 3.01 or $3.00 \AA$ ) relative to the calcite standard. Consistent with SEM-EDAX analysis, this shift results from appreciable substitution of $\mathrm{Mn}$ for $\mathrm{Ca}$ in the calcite. According to Krieger (1930), this decrease in basal reflection would indicate up to $7-15 \%$ of the rhodocrosite endmember, which would be classified as manganocalcite.

The middle part of Unit 3 is characterized by a decrease in both $\mathrm{CaCO}_{3}$ and $\mathrm{Mn}$ contents ( $\mathrm{Mn}$ from 0.1 to $1.8 \%$; Table 1 ). The $\mathrm{CaCO}_{3}$ is commonly lower than $20 \%$ and never higher than $30 \%$ (Table 1 ). The prevalent rock types are pelagic and hemipelagic marlstones and poorly laminated black shale. Thin turbidite beds interbedded with these fine-grained sediments are mainly composed of radiolarian shells filled with chalcedonic quartz (Fig. 4B) and record intra-basinal reworking of pelagic material. In the upper part of the section, the pelagic content of the turbidite beds is replaced by shallow-water grains from the Friuli Platform that foreshadow the overlying Vajont Limestone (Unit 4).

\subsubsection{Pyrite size distribution}

The morphology of sedimentary pyrite has been used to infer the oxygenation state of the environment of formation, whether within the water column or within the sediment during early diagenesis (Butler and Rickard, 2000; Taylor and Macquaker, 2000; Wilkin and Barnes, 1997; Wilkin et al., 1996). Essentially, the size distribution of pyrite framboids can discriminate between syngenetic pyrite formed in the water column of euxinic basins containing free hydrogen sulphide and early diagenetic pyrite formed within anoxic pore waters of sediments underlying dysoxic or oxic water columns (Wilkin et al., 1996). Framboids of syngenetic pyrite are on average smaller and less variable in size than early diagenetic framboids.

The framboidal pyrite population from the 1.5 to $10 \mathrm{~m}$ section in the lower part of Unit 3 is characterized by relatively large diameters (mean diameter ca $6 \mu \mathrm{m}$; see Fig. 4C and D) and by a wide range of size distribution. The points representative of selected samples fall in the oxic-dysoxic field of the discriminant diagram (Fig. 5) proposed by Wilkin et al. (1996). In contrast, the framboidal pyrite population of samples from the middle and upper parts of Unit 3 exhibits smaller diameters (mean diameter ca $3.6 \mu \mathrm{m}$ ) and less variability in size (Fig. 5), which would indicate precipitation in a euxinic water column.

\subsection{Geochemistry}

\subsubsection{Stable isotopes}

The limestone from Unit 2 and at the base of Unit 3 (Table 2: 0 to $1.3 \mathrm{~m}$; Fig. 6) shows a $\delta^{13} \mathrm{C}_{\text {carb }}$ mean value of $0.88 \%$, which drops sharply to $-11.15 \%$ at $1.4 \mathrm{~m}$ of the studied succession. Negative values (around $-9.0 \%$ ) are sustained across the interval from 1.4 to $2.1 \mathrm{~m}$. In the Mn-rich sediments from the lower part of Unit 3 (1.4 to $10 \mathrm{~m}), \delta^{13} \mathrm{C}_{\text {carb }}$ values generally fluctuate from -6.60 to $-1.01 \%$ 。 with some spikes down to $-18.37 \%$. In rock types from the middle and upper parts of the section (Mn-poor sediments and top limestone; see Fig. 6), there is an overall gradual increase in $\delta^{13} \mathrm{C}_{\text {carb}}$, from $-3.53 \%$ at $10.1 \mathrm{~m}$ to $1.05 \%$ at the top of Unit $3(28.8 \mathrm{~m})$, with rare negative spikes. As a whole, these values are relatively negative compared with those of other Toarcian marine pelagic carbonates, which range from about -1 to $4.5 \%$ o (Jenkyns and Clayton, 1986) and can be explained by the occurrence of diagenetic cement. Consistently low $\delta^{13} \mathrm{C}_{\text {carb }}$ values for the samples from the lower part of Unit 3 (1.4 to $10 \mathrm{~m}$ ) match high manganese contents $(r=-0.76 ; n=29$; Fig. 6$)$, suggesting that more negative $\delta^{13} \mathrm{C}_{\text {carb }}$ values correspond to higher $\mathrm{Mn}$ carbonate contents. In comparison, the most negative $\delta^{13} \mathrm{C}_{\text {carb }}$ values observed for similar coeval lower Toarcian Mn carbonate deposits from Úrkút (Hungary) are around -20\% (Polgári et al., 1991), whereas values around $-8 \%$ are reported for the Jurassic 

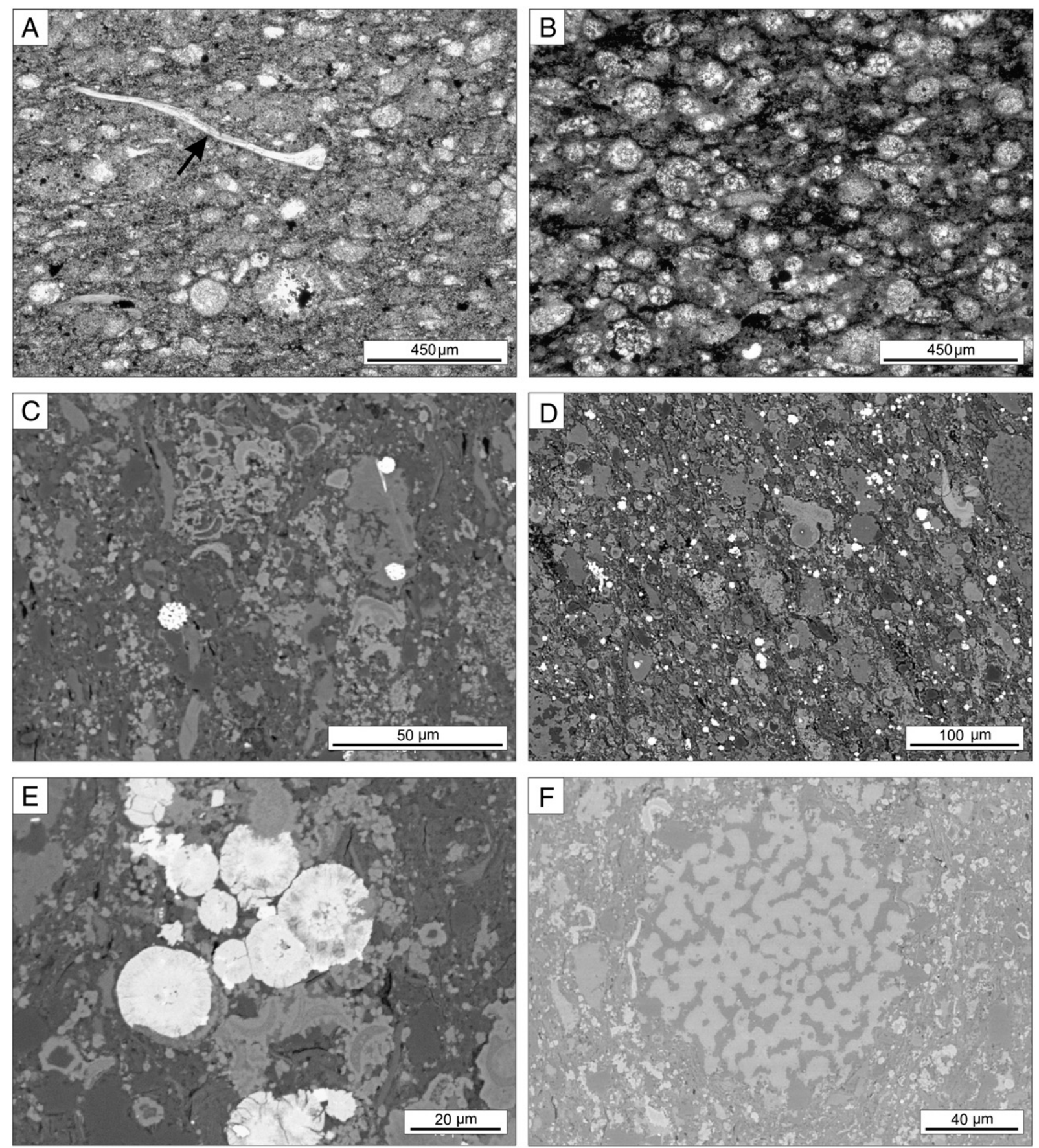

Fig. 4. Micrographs of rock types from Unit 3 in the Monte Mangart section. (A) Limestone ( $8.5 \mathrm{~m}$ ) showing well-preserved radiolarian tests filled with Mn calcite. Pyrite is present as framboids; phosphate debris (arrow) is also observable (plane-polarized light). (B) Siliceous limestone (21.5 m) with radiolarians preserved as microquartz and chalcedonic quartz (crossed polars). SEM images. (C) and (D) show Mn-rich samples respectively from 3 and $8.5 \mathrm{~m}$ of Unit 3 with calcite (intermediate grey) and Mn carbonate cements (lighter grey) together with clay (dark grey) and pyrite framboids (brightest white areas). (E) and (F) show details of the last sample (8.5 m) with spherical tests replaced by massive pyrite and a radiolarian test where biogenic opal is replaced by chalcedonic quartz (dark grey) and Mn carbonate (lighter grey).

Molango deposits (Mexico) (Okita and Shanks, 1992; Okita et al., 1988).

The $\delta^{18} \mathrm{O}$ values of whole-rock samples mostly range from -2.74 to $-0.12 \%$, but they become strongly negative, falling to $-11.04 \%$, for samples with the negative $\delta^{13} \mathrm{C}_{\text {carb }}$ spike (Table 2, Fig. 6). Similar values are reported for coeval carbonates from Mochras Borehole (Gwynedd) (Jenkyns and Clayton, 1997).

\subsubsection{Trace elements and bottom-water redox conditions}

The trace element proxy $\mathrm{V} /(\mathrm{V}+\mathrm{Ni})$ has been widely used in previous studies to evaluate palaeoredox conditions. Both $\mathrm{Ni}$ and $\mathrm{V}$ occur in highly stable tetrapyrrole structures originally derived from chlorophyll and preserved under anaerobic conditions (Breit and Wanty, 1991; Lewan and Maynard, 1982). Under euxinic conditions, the availability of $\mathrm{H}_{2} \mathrm{~S}$ causes the formation of soluble NiS complexes, whereas vanadyl or trivalent vanadium is produced (Lewan, 1984). In the sediments from Unit 3, the $\mathrm{V} /(\mathrm{V}+\mathrm{Ni})$ ratios are generally in the range 0.57-0.76 which, according to Hatch and Leventhal (1992), indicates deposition under anoxic bottom-water conditions. Along the lower part of this unit, the ratios are highly variable, indicating wide fluctuations from dysoxic/anoxic to anoxic/euxinic conditions (Fig. 6, Table 1). 
Table 1

Geochemical proxies for selected samples from Unit 2 and Unit 3 in the Monte Mangart section.

\begin{tabular}{|c|c|c|c|c|c|c|c|c|c|}
\hline $\begin{array}{l}\text { Height } \\
(\mathrm{m})\end{array}$ & $\begin{array}{l}\mathrm{CaCO}_{3} \\
(\%)\end{array}$ & $\begin{array}{l}\mathrm{S} \\
(\%)\end{array}$ & $\begin{array}{l}\mathrm{Mn} \\
(\%)\end{array}$ & $\begin{array}{l}\mathrm{Fe} \\
(\%)\end{array}$ & $\mathrm{V} /(\mathrm{V}+\mathrm{Ni})$ & $\begin{array}{l}(\mathrm{Co}+\mathrm{Ni}+\mathrm{Cu}) \\
(\mathrm{ppm})\end{array}$ & $\begin{array}{l}\sum \mathrm{REE} \\
(\mathrm{ppm})\end{array}$ & $\mathrm{Ce} / \mathrm{Ce}^{*}$ & $\mathrm{Eu} / \mathrm{Eu}^{*}$ \\
\hline \multicolumn{10}{|c|}{ Top limestones } \\
\hline 28.8 & 60 & 0 & 0.30 & 0.58 & 0.48 & 94.0 & 59.0 & 0.9 & 0.9 \\
\hline 28.6 & 56 & 0 & 0.25 & 0.51 & 0.55 & 100.0 & 47.5 & 0.9 & 1.0 \\
\hline \multicolumn{10}{|c|}{ Mn-poor sediments } \\
\hline 28.1 & 4 & 0.05 & 0.10 & 4.59 & 0.54 & 212.9 & 185.1 & 1.2 & 1.0 \\
\hline 27.4 & 15 & 0.07 & 0.23 & 3.94 & 0.54 & 220.8 & 268.7 & 1.2 & 1.0 \\
\hline 27 & 23 & 0.05 & 0.21 & 3.14 & 0.56 & 175.8 & 249.6 & 1.2 & 1.0 \\
\hline 26.6 & 27 & 0 & 0.33 & 3.64 & 0.71 & 116.2 & 258.1 & 1.4 & 1.0 \\
\hline 26.2 & 20 & 0.04 & 0.24 & 4.11 & 0.72 & 142.3 & 221.3 & 1.4 & 1.0 \\
\hline 25.8 & 27 & 0.04 & 0.35 & 3.18 & 0.73 & 89.8 & 213.4 & 1.4 & 1.0 \\
\hline 25.4 & 23 & 0 & 0.22 & 2.40 & 0.73 & 90.6 & 166.1 & 1.3 & 1.0 \\
\hline 25 & 25 & 0.04 & 0.25 & 3.15 & 0.74 & 113.2 & 214.4 & 1.2 & 1.0 \\
\hline 24.5 & 27 & 0.61 & 0.29 & 1.73 & 0.69 & 123.3 & 126.5 & 1.4 & 1.0 \\
\hline 24.2 & 24 & 1.01 & 0.33 & 1.55 & 0.64 & 127.7 & 120.6 & 1.3 & 1.0 \\
\hline 23.9 & 26 & 0.04 & 0.32 & 1.76 & 0.67 & 130.5 & 133.9 & 1.4 & 1.0 \\
\hline 23.6 & 30 & 0.07 & 0.40 & 1.15 & 0.64 & 84.2 & 158.5 & 0.9 & 0.9 \\
\hline 23.3 & 16 & 0.08 & 0.30 & 3.94 & 0.70 & 157.1 & 220.6 & 1.2 & 1.0 \\
\hline 23 & 23 & 0.05 & 0.35 & 2.98 & 0.71 & 175.9 & 197.6 & 1.2 & 1.0 \\
\hline 22.7 & 17 & 0.08 & 0.27 & 3.59 & 0.70 & 150.8 & 219.2 & 1.2 & 1.0 \\
\hline 22.4 & 15 & 0.07 & 0.30 & 3.49 & 0.69 & 172.1 & 195.3 & 1.2 & 1.0 \\
\hline 22.1 & 36 & 0.09 & 0.62 & 1.72 & 0.67 & 109.7 & 176.6 & 1.2 & 1.0 \\
\hline 21.8 & 13 & 0.66 & 0.25 & 1.70 & 0.68 & 311.8 & 83.1 & 1.2 & 1.0 \\
\hline 21.5 & 15 & 0.63 & 0.29 & 1.71 & 0.69 & 219.1 & 92.3 & 1.2 & 1.0 \\
\hline 21.2 & 32 & 0.04 & 0.43 & 4.05 & 0.65 & 179.0 & 233.6 & 1.2 & 1.0 \\
\hline 20.9 & 35 & 0.1 & 0.64 & 1.36 & 0.65 & 88.0 & 149.9 & 1.3 & 1.0 \\
\hline 20.6 & 21 & 1.18 & 0.21 & 1.55 & 0.67 & 136.6 & 136.4 & 1.7 & 1.0 \\
\hline 20.3 & 26 & 0.04 & 1.83 & 1.95 & 0.62 & 104.2 & 158.5 & 1.5 & 1.0 \\
\hline 20 & 31 & 0.96 & 0.92 & 2.09 & 0.60 & 94.9 & 146.5 & 1.4 & 1.0 \\
\hline 19.7 & 25 & 1.08 & 0.88 & 1.77 & 0.59 & 126.0 & 124.8 & 1.4 & 1.0 \\
\hline 19.4 & 23 & 1.59 & 0.82 & 2.30 & 0.59 & 185.4 & 133.2 & 1.4 & 0.9 \\
\hline 19.1 & 0 & 0.18 & 0.74 & 4.79 & 0.67 & 190.4 & 240.9 & 1.3 & 1.0 \\
\hline 18.8 & 15 & 1.35 & 0.30 & 2.92 & 0.67 & 150.7 & 179.7 & 1.2 & 1.0 \\
\hline 18.5 & 4 & 0.68 & 0.26 & 3.42 & 0.65 & 154.3 & 180.4 & 0.9 & 1.0 \\
\hline 18.2 & 1 & 1.01 & 0.16 & 3.96 & 0.68 & 156.7 & 183.1 & 1.1 & 1.0 \\
\hline 17.9 & 17 & 1.72 & 0.32 & 3.01 & 0.66 & 138.6 & 197.6 & 1.2 & 1.0 \\
\hline 17.6 & 7 & 1.31 & 0.21 & 4.05 & 0.68 & 133.8 & 206.8 & 1.1 & 1.0 \\
\hline 17.3 & 18 & 0.96 & 0.33 & 2.49 & 0.66 & 140.5 & 176.4 & 1.1 & 1.0 \\
\hline 17 & 22 & 1 & 0.46 & 1.94 & 0.68 & 163.9 & 166.4 & 1.3 & 1.0 \\
\hline 16.7 & 15 & 1.6 & 0.24 & 2.92 & 0.65 & 135.9 & 165.7 & 1.1 & 1.0 \\
\hline 16.4 & 27 & 1.33 & 0.73 & 2.65 & 0.63 & 160.0 & 130.2 & 1.3 & 1.0 \\
\hline 16.1 & 21 & 1.39 & 0.95 & 1.99 & 0.60 & 200.4 & 119.6 & 1.4 & 0.9 \\
\hline 15.8 & 21 & 2.34 & 0.40 & 3.71 & 0.65 & 126.7 & 166.4 & 1.3 & 1.0 \\
\hline 15.2 & 25 & 1.95 & 1.25 & 2.84 & 0.61 & 135.2 & 183.8 & 1.4 & 1.0 \\
\hline 14.6 & 24 & 1.35 & 0.38 & 1.64 & 0.66 & 147.8 & 121.0 & 1.2 & 1.0 \\
\hline 14.1 & 17 & 1.79 & 0.33 & 2.96 & 0.68 & 134.4 & 166.4 & 1.1 & 1.0 \\
\hline 13.7 & 25 & 1.27 & 0.57 & 2.10 & 0.64 & 126.3 & 144.0 & 1.2 & 1.0 \\
\hline 13.3 & 22 & 1.5 & 0.41 & 2.26 & 0.64 & 112.6 & 148.2 & 1.2 & 1.0 \\
\hline 12.9 & 12 & 1.15 & 0.24 & 1.55 & 0.68 & 212.2 & 96.1 & 1.3 & 1.0 \\
\hline 12.5 & 18 & 1.17 & 0.36 & 1.63 & 0.68 & 164.2 & 129.4 & 1.4 & 1.0 \\
\hline 12.1 & 13 & 1.03 & 0.26 & 1.67 & 0.68 & 178.7 & 121.6 & 1.3 & 1.0 \\
\hline 11.7 & 23 & 0.81 & 0.43 & 1.02 & 0.68 & 121.0 & 120.1 & 1.3 & 1.0 \\
\hline 11.3 & 20 & 1.23 & 0.34 & 1.73 & 0.69 & 127.2 & 144.9 & 1.3 & 1.0 \\
\hline 10.9 & 19 & 1.09 & 0.46 & 1.67 & 0.69 & 132.3 & 125.5 & 1.4 & 1.0 \\
\hline 10.5 & 19 & 1.53 & 0.60 & 2.34 & 0.69 & 127.1 & 153.0 & 1.3 & 1.0 \\
\hline 10.2 & 23 & 1.24 & 0.71 & 2.18 & 0.58 & 101.6 & 162.8 & 1.5 & 1.0 \\
\hline \multicolumn{10}{|c|}{ Mn-rich sediments } \\
\hline 9.8 & 22 & 0.85 & 5.51 & 1.55 & 0.72 & 116.1 & 142.7 & 1.2 & 1.0 \\
\hline 9.5 & 25 & 0.75 & 4.46 & 1.87 & 0.68 & 111.4 & 167.2 & 1.8 & 1.0 \\
\hline 9.1 & 35 & 0.17 & 8.80 & 4.03 & 0.68 & 142.6 & 342.3 & 1.9 & 1.0 \\
\hline 8.5 & 42 & 3.38 & 5.45 & 4.25 & 0.67 & 31.6 & 243.8 & 2.0 & 0.9 \\
\hline 8.1 & 18 & 1.67 & 0.76 & 2.20 & 0.68 & 111.0 & 322.2 & 2.0 & 1.0 \\
\hline 7.7 & 39 & 1.34 & 6.35 & 2.61 & 0.70 & 141.0 & 198.4 & 1.9 & 0.9 \\
\hline 7.3 & 39 & 2.49 & 6.14 & 3.52 & 0.73 & 85.8 & 375.9 & 2.0 & 1.0 \\
\hline 6.9 & 34 & 2.88 & 5.34 & 4.48 & 0.70 & 107.5 & 366.7 & 2.0 & 0.9 \\
\hline 6.5 & 26 & 1.96 & 1.07 & 3.02 & 0.67 & 131.8 & 408.8 & 2.0 & 1.0 \\
\hline 6.2 & 15 & 0.75 & 0.74 & 1.56 & 0.67 & 127.3 & 187.2 & 1.4 & 1.0 \\
\hline 5.8 & 24 & 0.39 & 1.48 & 2.54 & 0.63 & 138.7 & 93.7 & 1.2 & 1.0 \\
\hline 5.6 & 15 & 0.45 & 0.51 & 1.00 & 0.61 & 96.0 & 167.2 & 1.1 & 0.9 \\
\hline 5.4 & 25 & 0.9 & 1.19 & 1.57 & 0.57 & 118.4 & 94.0 & 1.1 & 0.9 \\
\hline 5 & 23 & 0.36 & 1.02 & 0.83 & 0.57 & 268.9 & 57.6 & 1.1 & 1.0 \\
\hline
\end{tabular}


Table 1 (continued)

\begin{tabular}{|c|c|c|c|c|c|c|c|c|c|}
\hline $\begin{array}{l}\text { Height } \\
(\mathrm{m})\end{array}$ & $\begin{array}{l}\mathrm{CaCO}_{3} \\
(\%)\end{array}$ & $\begin{array}{l}S \\
(\%)\end{array}$ & $\begin{array}{l}\text { Mn } \\
(\%)\end{array}$ & $\begin{array}{l}\mathrm{Fe} \\
(\%)\end{array}$ & $\mathrm{V} /(\mathrm{V}+\mathrm{Ni})$ & $\begin{array}{l}(\mathrm{Co}+\mathrm{Ni}+\mathrm{Cu}) \\
(\mathrm{ppm})\end{array}$ & $\begin{array}{l}\sum R E E \\
(\mathrm{ppm})\end{array}$ & $\mathrm{Ce} / \mathrm{Ce}^{*}$ & $\mathrm{Eu} / \mathrm{Eu}$ \\
\hline \multicolumn{10}{|c|}{ Mn-rich sediments } \\
\hline 4.6 & 24 & 0.84 & 1.62 & 2.31 & 0.59 & 126.3 & 144.3 & 1.4 & 0.9 \\
\hline 4.2 & 28 & 2.03 & 2.51 & 3.69 & 0.58 & 161.9 & 191.4 & 1.4 & 0.9 \\
\hline 3.8 & 22 & 1.34 & 5.96 & 3.21 & 0.65 & 127.3 & 240.0 & 1.5 & 0.9 \\
\hline 3.4 & 23 & 0.38 & 5.91 & 2.36 & 0.63 & 116.6 & 208.8 & 1.4 & 0.9 \\
\hline 3 & 24 & 0.25 & 5.79 & 1.81 & 0.62 & 112.4 & 202.3 & 1.4 & 0.9 \\
\hline 2.7 & 21 & 0.26 & 5.59 & 1.93 & 0.65 & 97.6 & 178.9 & 1.5 & 0.9 \\
\hline 2.3 & 51 & 0.16 & 6.78 & 1.18 & 0.65 & 49.0 & 130.8 & 1.4 & 0.9 \\
\hline \multicolumn{10}{|c|}{ Bottom limestones } \\
\hline 1.2 & 78 & 0.07 & 1.92 & 0.56 & 0.52 & 48.2 & 57.7 & 0.8 & 0.9 \\
\hline 0.9 & 63 & 0.04 & 0.87 & 0.80 & 0.71 & 59.8 & 58.4 & 0.7 & 0.9 \\
\hline \multicolumn{10}{|c|}{$\mathrm{Fe}-\mathrm{Mn}$ nodules } \\
\hline 0.8 & 20 & 0 & 13.20 & 16.10 & 0.50 & 79.3 & 65.7 & 1.1 & 0.9 \\
\hline 0.7 & 18 & 0 & 12.41 & 16.84 & 0.51 & 76.1 & 50.7 & 1.0 & 0.8 \\
\hline \multicolumn{10}{|c|}{ Bottom limestones } \\
\hline 0.6 & 49 & 0 & 0.57 & 1.24 & 0.64 & 63.1 & 55.6 & 0.6 & 1.0 \\
\hline 0.2 & 46 & 0 & 0.40 & 0.59 & 0.63 & 217.1 & 53.7 & 0.6 & 1.0 \\
\hline
\end{tabular}

Unit 3: upper part from 28.8 to $20.1 \mathrm{~m}$; middle part from 20 to $10.1 \mathrm{~m}$; lower part from 10 to $0.9 \mathrm{~m}$. Unit 2 : from 0.8 to $0.2 \mathrm{~m}$.

The total sulphur contents range from 0.16 to $3.38 \%$ for Mn-rich layers and from 0.04 to $2.34 \%$ for Mn-poor layers (Table 1 ). Consistently, microscopic observations revealed that the main sulphur-containing mineral is pyrite that occurs as framboidal aggregates (Fig. 4C and D) showing a decrease in the average diameter (from ca 6 to $c a 3.5 \mu \mathrm{m}$ ) between the lower (1.4 to $10 \mathrm{~m}$ ) and the middle-upper parts (10.1 to $28.1 \mathrm{~m}$ ) of Unit 3 (Fig. 5).

In the Fe-S-C diagram (Arthur and Sageman, 1994; Dean and Arthur, 1989), data points cluster along an area extending from the Fe corner to the $\mathrm{C}_{\text {org }}$-pyrite line (Fig. 7). Usually in euxinic sediments, the limiting factor in pyrite formation is not $\mathrm{C}_{\text {org }}$ content but the quantity of detrital reactive Fe present (Arthur and Sageman, 1994; Raiswell and Berner, 1985). In the sediments from Unit 3 of the Mangart section, sulphur fixation appears to have been controlled and limited by the availability of labile organic matter that generally was not sufficiently abundant to generate stable anoxic bottom-water conditions.

\subsubsection{REE distribution}

Several studies have indicated that the REE patterns in sedimentary systems are influenced by both depositional environment and

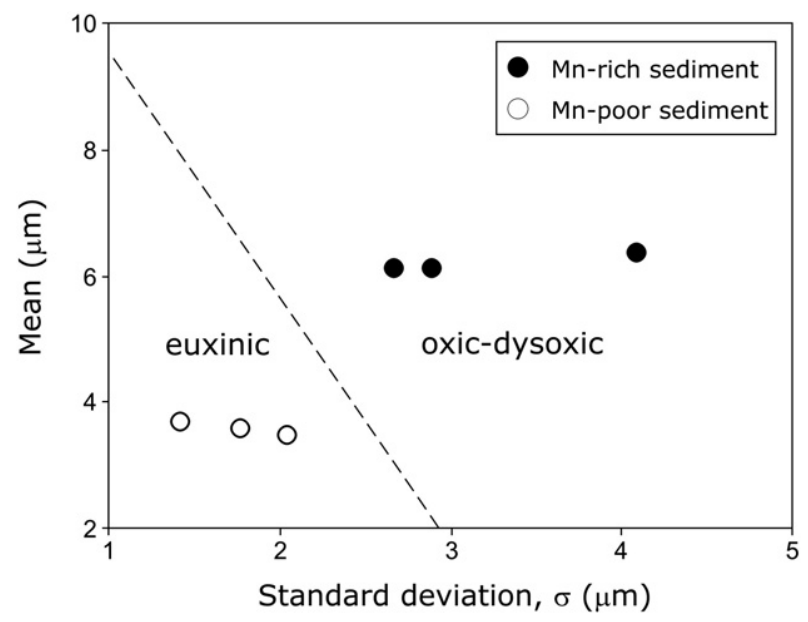

Fig. 5. Plot of the mean versus the standard deviation of pyrite framboid size distributions in selected samples. The proposed boundary (dashed line) is from Wilkin et al. (1996). diagenetic processes (Milodowski and Zalasiewicz, 1991; Murray et al., 1990, 1992). Limestones at the base and at the top of the Monte Mangart section show total REE contents ranging from 47 to $59 \mathrm{ppm}$ (Table 1). Fe-Mn nodules at the base of Unit 3 show a mean REE content of $58 \mathrm{ppm}$ (Table 1). The sediments from Unit 3 contain up to 409 ppm total REE (Table 1).

Cerium has been considered as a sensitive tracer for palaeoceanic redox conditions (Bellanca et al., 1997; German and Elderfield, 1990; Liu et al., 1988; Schijf et al., 1995; Wright et al., 1987), although this idea is controversial (de Baar et al., 1988; MacLeod and Irving, 1996). The $\mathrm{Ce} / \mathrm{Ce}^{*}$ values throughout the studied section show wide fluctuations (Fig. 6). The limestones at the base and the top of the section show moderate to weak negative Ce anomaly (mean values 0.6 and 0.9 , respectively), which may indicate oxygenated bottom waters during deposition. $\mathrm{Fe}-\mathrm{Mn}$ nodules show $\mathrm{Ce} / \mathrm{Ce}^{*}$ values close to 1 (Table 1 ). In the upper part of Unit 3 (above $10 \mathrm{~m}$ ), the $\mathrm{Ce} / \mathrm{Ce}^{*}$ ratio is on average slightly higher than 1 , which represents a typical value for average shale (Murray et al., 1991). Stratigraphically through the lower part (1.4 to $10 \mathrm{~m}$ ), Ce/Ce* values exhibit wider fluctuations ranging from 1 to 2 . Interestingly, the $\mathrm{Ce} / \mathrm{Ce}^{*}$ curve shows a striking similarity with the Mn profile (see Fig. 6), which suggests that the Ce anomaly is closely linked to conditions controlling the behaviour of manganese.

\section{Discussion}

\subsection{Mn fluctuations, sea-level variations and anoxia}

Some studies relate sedimentary Mn fluctuations to variations in sea-level (Accarie et al., 1989, 1993; Pratt et al., 1991; Renard and Letolle, 1983). Fluctuations in Mn content have, for example, been related to second-order eustatic sea-level variations (Corbin, 1994) and found to correspond with the transgressive-regressive cycles of the Jurassic Period, as defined by Hardenbol et al. (1998) and de Graciansky et al. (1998).

The early Toarcian OAE is characterized by a significant rise of eustatic sea-level that produced a marine transgression (Hallam, 1981, 1988; Haq et al., 1987). In the Monte Mangart section, higher concentrations of Mn appear to be superimposed on the general trend related to a hypothetical eustatic control (Fig. 8). In the stratigraphic interval from 1.4 to $15 \mathrm{~m}$, the abundant intercalations of limestone rich in radiolarian tests could represent the transgression maximum (Šmuc and Goričan, 2005). At the same stratigraphic interval, a peak 
Table 2

Carbonate stable isotopes for samples from Unit 2 and Unit 3 in the Monte Mangart section.

\begin{tabular}{|c|c|c|c|c|c|c|c|c|}
\hline $\begin{array}{l}\text { Height } \\
(\mathrm{m})\end{array}$ & $\begin{array}{l}\delta^{13} \mathrm{C}_{\mathrm{carb}} \\
(\% \circ)\end{array}$ & $\begin{array}{l}\delta^{18} \mathrm{O}_{\text {carb }} \\
(\% \circ)\end{array}$ & $\begin{array}{l}\text { Height } \\
(\mathrm{m})\end{array}$ & $\begin{array}{l}\delta^{13} C_{\text {carb }} \\
(\% \circ)\end{array}$ & $\begin{array}{l}\delta^{18} \mathrm{O}_{\text {carb }} \\
(\% \circ)\end{array}$ & $\begin{array}{l}\text { Height } \\
(\mathrm{m})\end{array}$ & $\begin{array}{l}\delta^{13} C_{\text {carb }} \\
(\% \circ)\end{array}$ & $\begin{array}{l}\delta^{18} \mathrm{O}_{\text {carb }} \\
(\%)\end{array}$ \\
\hline 28.8 & 1.05 & -1.56 & 13.5 & -2.27 & -1.41 & 6.3 & -2.72 & -1.51 \\
\hline 28.6 & 0.96 & -1.39 & 13.3 & -1.37 & -1.37 & 6.2 & -2.49 & -1.61 \\
\hline 28.4 & 1.20 & -0.73 & 13.1 & -0.12 & -0.85 & 6.1 & -2.48 & -1.49 \\
\hline 28.1 & 0.10 & -1.43 & 12.9 & -2.02 & -1.83 & 6.0 & -1.33 & -1.57 \\
\hline 27.8 & -0.20 & -1.09 & 12.7 & -1.58 & -1.50 & 5.9 & -1.78 & -1.56 \\
\hline 27.6 & -0.37 & -0.90 & 12.5 & -2.06 & -1.88 & 5.8 & -2.22 & -1.44 \\
\hline 27.4 & -0.07 & -0.96 & 12.3 & -2.02 & -1.04 & 5.7 & -3.33 & -1.74 \\
\hline 27.2 & -0.23 & -1.35 & 12.1 & -1.90 & -1.85 & 5.6 & -4.10 & -1.57 \\
\hline 27.0 & 0.04 & -1.32 & 11.9 & -2.33 & -1.76 & 5.5 & -3.29 & -2.38 \\
\hline 26.8 & -0.02 & -1.17 & 11.7 & -2.34 & -2.08 & 5.4 & -2.97 & -1.42 \\
\hline 26.6 & -0.13 & -0.89 & 11.5 & -3.06 & -1.85 & 5.3 & -3.37 & -1.70 \\
\hline 26.4 & -0.11 & -1.16 & 11.3 & -3.36 & -1.51 & 5.1 & -3.17 & -1.34 \\
\hline 26.2 & -0.30 & -0.65 & 11.1 & -3.60 & -1.67 & 5.0 & -2.55 & -2.04 \\
\hline 26.0 & -0.39 & -1.27 & 10.9 & -2.29 & -1.53 & 4.9 & -2.31 & -1.48 \\
\hline 25.8 & -0.12 & -1.23 & 10.7 & -3.57 & -1.49 & 4.8 & -2.11 & -1.84 \\
\hline 25.6 & -0.15 & -1.74 & 10.6 & -2.43 & -1.78 & 4.7 & -3.00 & -1.53 \\
\hline 25.4 & -0.88 & -1.33 & 10.5 & -2.99 & -1.49 & 4.6 & -2.10 & -1.22 \\
\hline 25.2 & -0.37 & -1.31 & 10.4 & -2.82 & -1.52 & 4.5 & -2.47 & -1.65 \\
\hline 25.0 & -0.79 & -1.37 & 10.3 & -2.76 & -1.61 & 4.4 & -2.85 & -1.91 \\
\hline 24.8 & -1.29 & -1.52 & 10.2 & -2.41 & -1.70 & 4.3 & -2.96 & -1.73 \\
\hline 24.5 & -1.43 & -1.61 & 10.1 & -3.53 & -1.66 & 4.2 & -2.83 & -1.50 \\
\hline 24.2 & -1.68 & -1.55 & 10.0 & -6.60 & -2.79 & 4.1 & -2.55 & -1.00 \\
\hline 23.9 & -1.65 & -1.88 & 9.9 & -1.49 & -1.35 & 4.0 & -1.82 & -1.77 \\
\hline 23.6 & -2.12 & -1.79 & 9.8 & -6.33 & -1.59 & 3.9 & -3.53 & -1.70 \\
\hline 23.3 & -3.81 & -1.40 & 9.7 & -6.47 & -1.76 & 3.8 & -5.53 & -1.33 \\
\hline 23.0 & -5.67 & -3.18 & 9.6 & -5.53 & -0.96 & 3.7 & -11.36 & -0.35 \\
\hline 22.7 & -1.52 & -1.60 & 9.5 & -4.47 & -1.34 & 3.6 & -2.82 & -2.53 \\
\hline 22.4 & -2.76 & -2.63 & 9.4 & -16.89 & -9.69 & 3.5 & -2.26 & -2.41 \\
\hline 22.1 & -0.63 & -1.26 & 9.3 & -9.73 & -3.65 & 3.4 & -5.36 & -1.20 \\
\hline 21.8 & -1.71 & -1.62 & 9.2 & -18.37 & -11.04 & 3.3 & -5.97 & -1.33 \\
\hline 21.5 & -1.64 & -1.60 & 9.1 & -4.47 & -2.15 & 3.2 & -5.11 & -1.09 \\
\hline 21.2 & -0.65 & -1.17 & 9.0 & -4.89 & -1.10 & 3.1 & -5.27 & -1.24 \\
\hline 20.9 & -0.84 & -0.92 & 8.9 & -1.82 & -2.62 & 3.0 & -5.42 & -1.23 \\
\hline 20.6 & -1.12 & -1.58 & 8.8 & -8.92 & -1.87 & 2.9 & -5.37 & -1.26 \\
\hline 20.3 & -2.12 & -1.06 & 8.7 & -2.37 & -4.42 & 2.8 & -4.89 & -1.10 \\
\hline 20.0 & -2.14 & -1.15 & 8.5 & -4.85 & -1.75 & 2.7 & -3.84 & -1.16 \\
\hline 19.7 & -2.70 & -1.26 & 8.4 & -4.47 & -1.74 & 2.6 & -4.12 & -0.91 \\
\hline 19.4 & -2.10 & -1.64 & 8.3 & -3.98 & -1.82 & 2.5 & -4.65 & -1.09 \\
\hline 19.1 & -8.28 & -4.81 & 8.2 & -2.34 & -1.45 & 2.4 & -3.26 & -0.67 \\
\hline 18.8 & -2.30 & -1.54 & 8.1 & -1.66 & -1.32 & 2.3 & -2.41 & -0.12 \\
\hline 18.2 & -4.84 & -0.61 & 8.0 & -1.83 & -1.95 & 2.2 & -3.35 & -0.28 \\
\hline 17.9 & -2.55 & -1.11 & 7.9 & -2.30 & -1.70 & 2.1 & -9.19 & -0.76 \\
\hline 17.6 & -1.93 & -1.76 & 7.8 & -2.01 & -1.81 & 2.0 & -8.41 & -0.41 \\
\hline 17.3 & -1.55 & -1.35 & 7.7 & -4.67 & -1.96 & 1.9 & -8.66 & -0.31 \\
\hline 17.0 & -3.61 & -1.55 & 7.6 & -4.49 & -2.06 & 1.8 & -8.89 & -1.12 \\
\hline 16.7 & -1.70 & -1.06 & 7.5 & -2.42 & -1.73 & 1.7 & -6.89 & -5.26 \\
\hline 16.4 & -2.20 & -1.60 & 7.4 & -4.27 & -1.85 & 1.6 & -6.78 & -3.89 \\
\hline 16.1 & -2.97 & -1.46 & 7.3 & -4.67 & -1.66 & 1.5 & -11.08 & -7.06 \\
\hline 15.8 & -1.89 & -1.18 & 7.2 & -4.22 & -1.73 & 1.4 & -11.15 & -5.93 \\
\hline 15.5 & -3.23 & -2.75 & 7.1 & -4.35 & -1.65 & 1.3 & -1.06 & -0.72 \\
\hline 15.2 & -2.22 & -1.46 & 7.0 & -4.11 & -1.70 & 1.2 & 0.42 & -0.66 \\
\hline 14.9 & -3.24 & -2.14 & 6.9 & -3.87 & -1.91 & 1.1 & 0.58 & -0.82 \\
\hline 14.6 & -3.21 & -2.60 & 6.8 & -2.81 & -3.56 & 0.9 & 0.65 & -1.06 \\
\hline 14.3 & -2.21 & -1.83 & 6.7 & -14.29 & -1.60 & 0.8 & 0.87 & -1.58 \\
\hline 14.1 & -2.52 & -1.66 & 6.6 & -1.02 & -2.26 & 0.6 & 1.03 & -1.50 \\
\hline 13.9 & -1.80 & -1.12 & 6.5 & -2.17 & -1.79 & 0.4 & 1.17 & -1.43 \\
\hline 13.7 & -2.24 & -1.68 & 6.4 & 2.39 & -1.52 & 0.2 & 1.23 & -1.57 \\
\hline
\end{tabular}

Unit 3: upper part from 28.8 to $20.1 \mathrm{~m}$; middle part from 20 to $10.1 \mathrm{~m}$; lower part from 10 to $0.9 \mathrm{~m}$. Unit 2: from 0.8 to $0.2 \mathrm{~m}$.

Top limestone: from 28.8 to $28.2 \mathrm{~m}$. Mn-poor sediment: from 28.1 to $10.1 \mathrm{~m}$. Mn-rich sediment: from 10 to $1.4 \mathrm{~m}$. Bottom limestone: from 1.3 to $0.2 \mathrm{~m}$.

in abundance of the radiolarian family Pantanelliidae was recorded, indicating the maximum development of eutrophic conditions (Goričan et al., 2003). Rise of eustatic sea level and enhanced global oceanic Mn flux could have characterized the early Toarcian as a result of hydrothermal activity during rapid seafloor spreading (Corbin et al., 2000). However, the high Mn contents measured in the lower part of Monte Mangart section might not be justified solely by an increase in hydrothermal inputs during the most active expansion phase of midoceanic ridges.

Higher Mn concentrations in the Monte Mangart section are coeval with negative $\delta^{13} \mathrm{C}$ shifts (Fig. 6). This relationship suggests that an additional source of Mn might be related to the events responsible for the negative isotopic excursions characterizing the T-OAE (Hermoso et al., 2009a; Jenkyns, 2003; Jenkyns and Clayton, 1986, 1997; Jenkyns et al., 2002; Sabatino et al., 2009).

Although the T-OAE is characterized by an overarching positive carbon-isotope excursion (Jenkyns, 1988; Jenkyns and Clayton, 1997), as would be expected for an interval of globally significant organic carbon burial, lower Toarcian black shales are everywhere typically associated with a negative $\delta^{13} \mathrm{C}$ excursion in bulk marine organic matter, bulk and skeletal carbonate, and also in fossil wood (AlSuwaidi et al., 2010; Hermoso et al., 2009b; Hesselbo et al., 2000, 

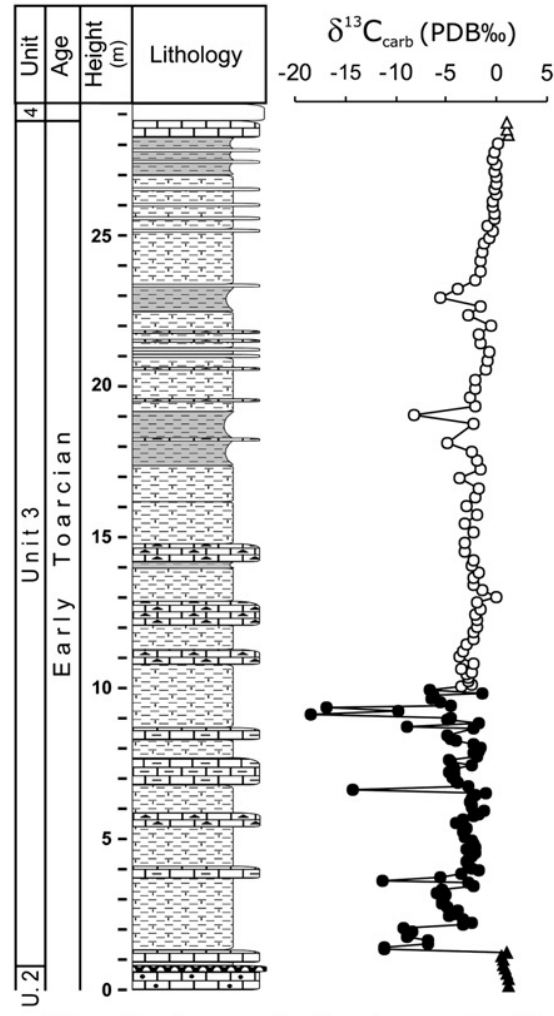

$\delta^{18} \mathrm{O}_{\text {carb }}(\mathrm{PDB} \%)$

$\begin{array}{llllllll}-12 & -10 & -8 & -6 & -4 & -2 & 0\end{array}$

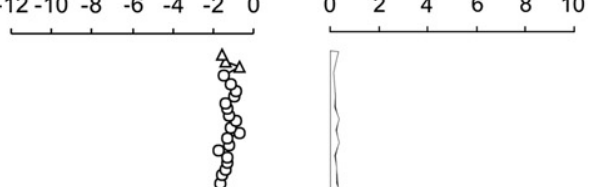

Bottom limestone $\Delta$ Top limestone

- Mn-rich sediment

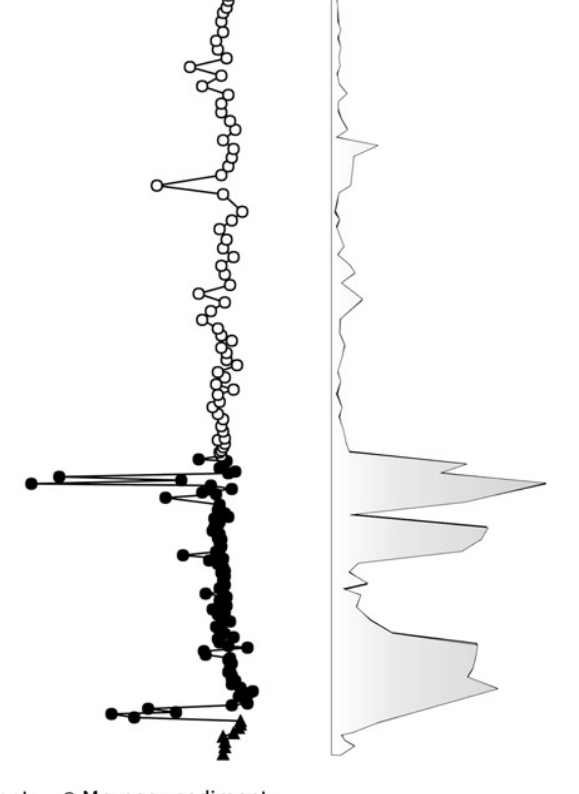

$\mathrm{Ce} / \mathrm{Ce} *$

$\begin{array}{lllll}0.5 & 1.0 & 1.5 & 2.0 & 2.5\end{array}$
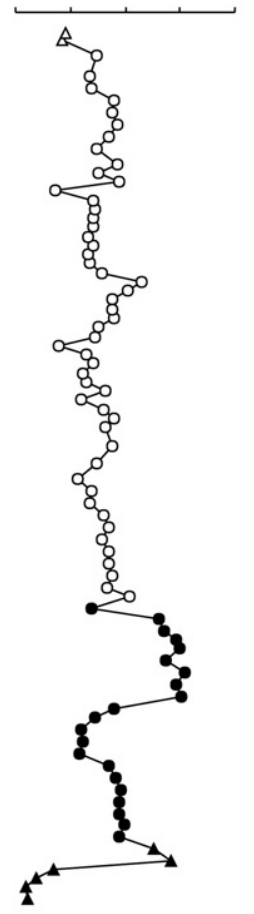

$\mathrm{V} /(\mathrm{V}+\mathrm{Ni})$

$\begin{array}{lllll}0,4 & 0,5 & 0,6 & 0,7 & 0,8\end{array}$

Fig. 6. Carbon- and oxygen-isotope stratigraphy with $\mathrm{Mn}, \mathrm{Ce} / \mathrm{Ce}^{*}$ and $\mathrm{V} /(\mathrm{V}+\mathrm{Ni})$ depth profiles from the Monte Mangart section. Key for lithology as in Fig. 2 .

2007; Jenkyns, 2010; Jenkyns et al., 2001; Kemp et al., 2005; Schouten et al., 2000; Suan et al., 2008; Woodfine et al., 2008). These records resulted from the rapid release to the ocean and atmosphere of isotopically light carbon, possibly sourced from biogenic methane $\left(\delta^{13} \mathrm{C}=\mathrm{ca}-60 \%\right.$ ) by dissociation of methane hydrates in continental margin sediments during periods of relatively warm climate and/or tectonic instability (Beerling et al., 2002; Hesselbo et al., 2000; Hesselbo et al., 2007; Jenkyns, 2003; Jenkyns et al., 2002; Kemp et al., 2005; Röhl et al., 2001). Methane oxidation involves increased consumption of oxygen and would have been one of the factors promoting anoxia.

These considerations argue for conditions favourable to the development, during the early Toarcian, of an oxygen minimum

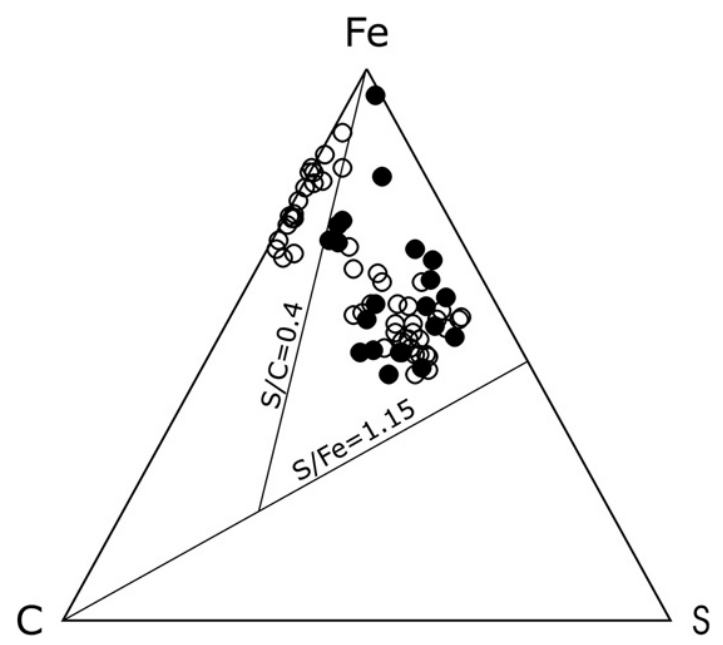

Fig. 7. Distribution of Monte Mangart data in the Fe-S-C ternary diagram. Total Organic Carbon (TOC) data from Sabatino et al. (2009). The normal marine line $(S / C=0.4)$ and pyrite line are shown. Symbols as in Fig. 6. layer along the Tethyan continental margin (Jenkyns et al., 1991) where fluctuations of the redox front into the water column or within the sediment could have induced Mn oxide reduction. Dissolving Mn oxides are a significant source for $\mathrm{Mn}^{2+}$ that can be incorporated into the lattice of early diagenetic carbonates. The development of an oxygen minimum zone across the Tethyan continental margin, variably enriched in dissolved $\mathrm{Mn}^{2+}$, could explain the origin of central European Mn-rich deposits with a strong difference in the degree of enrichment between the Hungarian (high enrichment) and Italian (moderate enrichment) deposits (Jenkyns et al., 1991). In Greece (Ionian Zone) and in the Umbria-Marche Basin, black shale records of the T-OAE are present, but Mn mineralization is absent.

\subsection{Origin of $\mathrm{Fe}-\mathrm{Mn}$ nodules}

The Julian Basin was part of the southern continental margin of the Tethys Ocean during the Mesozoic. The Early Jurassic rifting produced a complex pattern of structural highs and lows (seamounts and basins) developing distinct palaeoenvironments (Bernoulli and Jenkyns, 1974, 2009). On submarine topographic highs, long periods of exposure of the sea floor to oxygenated seawater favoured metal precipitation in form of $\mathrm{Mn}$ and $\mathrm{Fe}$ (hydr) oxides on any available substrate, potentially promoting conditions conducive to formation of a hardground with Fe-Mn nodules (Jenkyns, 1970; Di Stefano and Mindszenty, 2000; Di Stefano et al., 2002), as seen at the base of the Monte Mangart section (Fig. 2C).

Fe-Mn nodules from Monte Mangart are defined by low contents of $\mathrm{Co}+\mathrm{Ni}+\mathrm{Cu}$ (mean value $77.7 \mathrm{ppm}$, Table 1) that resemble the composition of hydrothermal manganese deposits formed by lowtemperature hydrothermal fluids (Glasby et al., 1997). The dominant controls on element concentrations in the nodules include element concentrations in seawater, colloid surface charge, degree of oxidation, types of complexing agents, physical properties, and growth rates (e.g. Li, 1981). During the growth of the Fe-Mn oxide, its 


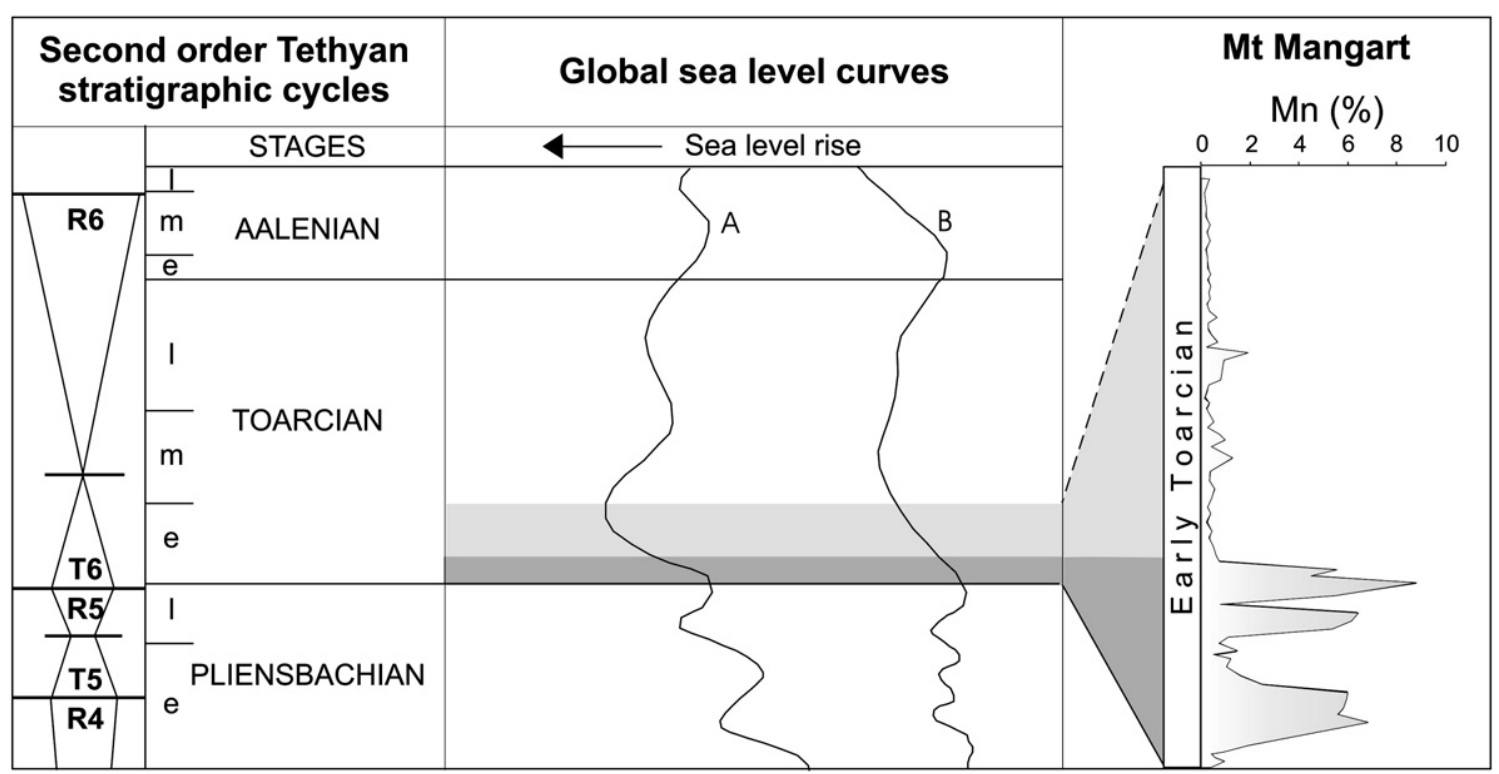

Fig. 8. Transgressive (T)-regressive ( $\mathrm{R}$ ) cycles for the Early Jurassic (e=Early, $\mathrm{m}=$ Middle, $\mathrm{l}=$ Late) ( for the Monte Mangart section and the global eustatic sea-level curves: (A) Hallam (1988), (B) Haq et al. (1987).

exposed surface is progressively buried and this process controls the $\mathrm{Co}, \mathrm{Ni}$, and $\mathrm{Cu}$ enrichments (Manceau et al., 1997; Takematsu et al., 1989). Although it is well known that trivalent Co is strictly associated with Mn oxides (Takahashi et al., 2007) and its abundance decreases on average from hydrogenetic to diagenetic to hydrothermal oxide deposits (Usui et al., 1997), it has been suggested that its enrichment is controlled by the growth rate of the ferromanganese oxide, a fast growth resulting in limited uptake of $\mathrm{Co}$ (and $\mathrm{Ni}$ and $\mathrm{Cu}$ ) from seawater (Hein et al., 1997; Takahashi et al., 2007; Usui et al., 1997). On this basis, the low metal concentration of $\mathrm{Fe}-\mathrm{Mn}$ nodules from Monte Mangart could indicate a hydrothermal origin in part, but alternatively a rapid growth of hydrogenous or diagenetic nodules cannot be ruled out. SEM/EDS analyses indicate that the nodules have a black core dominated by Mn oxides, which is consistent with a hydrothermal input, given that such precipitates are general markedly enriched in $\mathrm{Mn}$ and depleted in $\mathrm{Fe}$, as compared with hydrogenetic or diagenetic deposits (Usui et al., 1997).

The low REE contents (mean value $\Sigma R E E=58$ ppm, Table 1 ) of FeMn nodules from the Mangart section are similar to those reported for micronodules in the Trans-Atlantic Geotraverse hydrothermal fields (Dekov et al., 2003; Rona et al., 1986). However, the REE distribution patterns of the nodules do not indicate unequivocally a hydrothermal origin. Common features of REE distribution in hydrothermal manganese deposits from mid-ocean ridge are the negative $\mathrm{Ce}$ anomaly and a large positive Eu anomaly (Danielson et al., 1992; Michard and Albarède, 1986). The reasons for these characteristics are that (i) fluids of submarine hydrothermal systems are enriched in Eu and depleted in Ce (Douville et al., 1999; Michard and Albarède, 1986) and (ii) hydrothermal Fe-Mn oxides inherit the negative Ce anomaly of seawater, the dominant fluid in hydrothermal Mn mineralization. Additional Ce adsorption on the surface of Fe-Mn oxides is kinetically hindered in fast-growing hydrothermal ferromanganese oxides (e.g. Takahashi et al., 2007). Conversely, the studied nodules do not display Ce anomalies ( $\mathrm{Ce} / \mathrm{Ce}^{*} \mathrm{ca} 1$, Table 1 ) and have a weak negative Eu anomaly $\left(\mathrm{Eu} / \mathrm{Eu}^{*}=0.8\right)$. The lack of a pronounced positive $\mathrm{Eu}$ anomaly may be related to a relatively remote hydrothermal source and/or high dilution by seawater (Lottermoser, 1992; Michard, 1989). Also, Usui et al. (1997) ascribed negative Eu anomalies of Central Pacific Mn oxide deposits to formation from low-temperature hydrothermal fluids. According to the model of Dubinin (2004), FeMn hydrothermal nodules in hydrothermal-sedimentary deposits can change their REE composition through diagenesis and/or in relation to increased hydrogenetic particulate flux, mainly Fe-Mn oxyhydroxide particulates, which are known to accumulate $\mathrm{Ce}$ in oxidizing environments. This model could explain the lack of a distinct negative Ce anomaly in ferromanganese nodules from the base of Unit 3 in the Monte Mangart section.

Although trace-metal and REE distribution patterns in the nodules do not indicate unequivocally their origin, it is plausible that the formation of the studied nodules was triggered by release of $\mathrm{Mn}$ from hydrothermal vents into a region of relatively elevated submarine topography (seamount) where oxidizing conditions prevailed. Evidence of a hydrothermal source for $\mathrm{Mn}$ is largely indirect, although Toarcian volcanicity is known from parts of the Tethyan region and Germann (1972) recorded a tuff interbedded with manganese deposits in the northern Calcareous Alps of Austro-Germany. The nodules show a black core dominated by Mn oxides and a Fe-rich brown shell. This variation in the nodule chemistry/mineralogy could be an expression of changes in bottom-water redox conditions in the Julian Basin. During the initial stage of high bottom-water oxygenation, large amounts of Mn oxides precipitated from the water column to the sediment. Then, continous oxide accumulation after the particles have settled on the seafloor and Ce uptake by oxidative scavenging took place leading to $\mathrm{Ce} / \mathrm{Ce}^{*}$ ratios close to 1 . In the initial stage of the early Toarcian Oceanic Anoxic Event, variation of oxidation state resulted into moderately reducing bottom-water conditions that favoured precipitation of iron oxide phases in the nodules, Mn being much more soluble in oxygen-deficient settings.

\subsection{Depositional environment of Mn-rich deposits from Monte Mangart}

Above the hardground, Unit 3 displays a transition from Mn-rich (up to 8.80\%) sediments, at the base (below $10 \mathrm{~m}$ ), to Mn-poor (less than $1.83 \%$ ) sediments through the middle and upper parts of the unit (Table 1 and Fig. 6). The drastic decrease in Mn concentration is consistent with a decrease in size of pyrite framboids (mean diameter from ca 6 to $c a 3.6 \mu \mathrm{m}$, Fig. 5) which, in accordance with Wilkin et al. (1996), indicates a change from an oxic-dysoxic to an anoxic-euxinic water column.

With respect to the lower part of Monte Mangart section, wide fluctuations in the $\mathrm{V} /(\mathrm{V}+\mathrm{Ni}$ ) record (Fig. 6) indicate variations in the dissolved oxygen contents in the bottom waters. Higher $\mathrm{V} /(\mathrm{V}+\mathrm{Ni})$ 
ratios, roughly coincident with higher Mn concentrations, support the idea that Mn enrichments can be related to manganese accumulation driven by fluctuating redox conditions at the sediment-water interface (Heiser et al., 2001; Huckriede and Meischner, 1996; Jenkyns et al., 1991) during the early Toarcian. Higher Mn percentages and higher $\mathrm{V} /(\mathrm{V}+\mathrm{Ni})$ ratios are also coincident with strongly positive values of the $\mathrm{Ce}$ anomaly ( $\mathrm{Ce} / \mathrm{Ce}^{*}$ up to 1.89 , Fig. 6$)$. The positive $\mathrm{Ce}$ anomaly appears related to $\mathrm{Mn}$ carbonate precipitation during early diagenesis from anoxic pore waters. Ce is bound to Mn (Fig. 6) due to processes of combined oxidation expressed by the reaction:

$\mathrm{Fe}-\mathrm{O}-\mathrm{Mn}-(\mathrm{OH})_{3}+\mathrm{Ce}_{(\mathrm{s})}^{3+}+\mathrm{O}_{2}+\mathrm{H}_{2} \mathrm{O}=\mathrm{Fe}-\mathrm{O}-\mathrm{Mn}-(\mathrm{OH})_{2}-\mathrm{O}-\mathrm{Ce}-(\mathrm{OH})_{3}$

on which basis if $\mathrm{Mn}$ is reduced, Ce is also reduced to the trivalent state. In anoxic environments, $\mathrm{Ce}^{4+}$ sorbed onto Mn oxyhydroxides is reduced to $\mathrm{Ce}^{3+}$, mobilized and then released into the water column or to pore water where precipitation of authigenic phases (such as Mn carbonate) may occur (Dolenec et al., 2001; German and Elderfield, 1990, Holser, 1997; Rantitsch et al., 2003).

Mn carbonate precipitation in the lower part of Unit 3 may have taken place as a product of bacterially mediated degradation of organic matter. At the sediment/water interface, and in the top few decimetres of sediment, redox reactions related to the decay of organic matter play an important role in early diagenetic processes (Froelich et al., 1979). As dissolved oxygen becomes depleted, organic matter decomposes by using $\mathrm{O}_{2}$ from secondary oxidant sources (such as $\mathrm{MnO}_{2}$ ), thus releasing $\mathrm{Mn}^{2+}$ in interstitial solutions (suboxic diagenesis) according to the reactions:

$\mathrm{SO}_{4}^{2-}+2 \mathrm{CH}_{2} \mathrm{O}=\mathrm{HS}^{-}+2 \mathrm{HCO}_{3}^{-}+\mathrm{H}^{+}$

$2 \mathrm{MnO}_{2(\mathrm{~s})}+\mathrm{CH}_{2} \mathrm{O}+3 \mathrm{H}^{+}=2 \mathrm{Mn}^{2+}+\mathrm{HCO}_{3}^{-}+2 \mathrm{H}_{2} \mathrm{O}$

The rate of these reactions may depend on the supply of organic matter. Manganese sequestration within the sediment can occur by coprecipitation within the calcite lattice and this process depends on the $\mathrm{pH}, \mathrm{Eh}, \mathrm{O}_{2}$, Mn and $\left(\mathrm{HCO}_{3}\right)^{-}$contents of pore waters (Frakes and Bolton, 1984; Stumm and Morgan, 1981). Although opaline tests may dissolve in interstitial waters undersaturated with respect $\mathrm{SiO}_{2}$, calcitized radiolarian shells in Mn-rich samples from the Mangart section (see Fig. 4A and F) may indicate high pore water alkalinity, under which the tests could also have been dissolved. High alkalinity resulting from intense bacterial sulphate reduction (Berner, 1970), and from manganese reduction coupled with oxidation of organic matter, could have favoured early diagenetic Mn carbonate precipitation.

An involvement of organic matter in the mineralization process is supported by the coincidence of high Mn contents with negative $\delta^{13} \mathrm{C}_{\text {carb }}$ values (down to $-18.37 \%$ ) (Fig. 6) and low hydrogen index ( $80 \mathrm{mg} \mathrm{HC} / \mathrm{g}$ TOC, Sabatino et al., 2009) that indicate highly degraded planktonic organic matter. The negative $\delta^{13} \mathrm{C}$ values measured in the Mn-rich sediments of the lower part of Unit 3 may be the result of mixing of two carbon reservoirs: i) isotopically light, organic matterderived $\mathrm{CO}_{2}$ with a composition of about $-30 \%$, as measured by Sabatino et al. (2009), and ii) $\mathrm{HCO}_{3}^{-}$with $\delta^{13} \mathrm{C}$ close to $0 \%$ derived from seawater, as assumed from $\delta^{13} \mathrm{C}$ carbonate values (near $-2 \%$ ) of unmineralized samples from the middle and upper part of Unit 3. From a simple mass balance, it can be estimated that up to $60 \%$ of the carbon involved in $\mathrm{Mn}$ carbonate precipitation originated from $\mathrm{CO}_{2}$ produced during degradation of organic matter. Also the negative $\delta^{18} \mathrm{O}_{\text {carb }}$ values of the Mn-rich layers (Fig. 6) may reflect precipitation from pore water altered by diagenetic reactions, which is consistent with the supposed origin of the carbonate cements from decomposition of organic matter in an oxygen-depleted environment (Krajewski et al., 2001). According to Sass et al. (1991), carbonates precipitated in the sulphate reduction zone are enriched with ${ }^{16} \mathrm{O}$ and it is possible that organic matter itself can be a source of ${ }^{16} \mathrm{O}$.
The mineralization process of precipitation of Mn carbonate, observed in the lower part of Unit 3, was manifestly interrupted during periods of more oxygenated conditions in the water column, as highlighted by low values of the $\mathrm{V} /(\mathrm{V}+\mathrm{Ni})$ ratio and $\mathrm{Ce} / \mathrm{Ce}^{*}$ in coincidence with low concentrations of Mn. The Mn-rich deposits of Monte Mangart could be an analogue of the recent sapropelic sediments of the central Baltic Sea, where Ca-rich rhodochrosite formation has been related to the periodic renewal of deep water (Neumann et al., 2002).

\section{Conclusion}

The origin of the Mn enrichment in the Monte Mangart section is related to the early Toarcian OAE that occurred during a marine transgression. The high Mn concentrations are not consistent solely with a hydrothermal source, even though the early Toarcian was a time of active expansion of mid-oceanic ridges. Rather, an additional source of sedimentary or early diagenetic $\mathrm{Mn}$ is required.

On the basis of petrographic and geochemical observations, different stages can be distinguished in the deposition of the studied section. During the first stage, the deposition of Fe-Mn nodules at the base of the Monte Mangart section was triggered by release of Mn from remote hydrothermal vents into a region of relatively elevated submarine topography. In the second stage, sediment deposition occurred under conditions of increasing productivity and flux of organic matter. During the early Toarcian, the basin was invaded by oxygen-depleted waters, and the development of a fluctuating oxygen minimum zone led to diffusion of $\mathrm{Mn}^{2+}$ from the dissolution of $\mathrm{Fe}-\mathrm{Mn}$ oxyhydroxides. The Mn enrichment in the lower part of Unit 3 may have been related to sulphate reduction that resulted in increased $\mathrm{pH}$ of interstitial waters in sediments just below the sea floor: high alkalinity in combination with high $\mathrm{Mn}^{2+}$ concentrations induced precipitation of authigenic Mn carbonate. During the third stage, anoxic/euxinic conditions became dominant with the deposition of pelagic marlstones and black shales containing small-diameter pyrite framboids and low concentrations of $\mathrm{Mn}$, in the middle and upper parts of Unit 3.

\section{Acknowledgements}

The authors would like to thank Dr. N. Charnley (Earth Sciences Department) for isotope analyses performed during a visit of NS to Oxford University. Anonymous reviewers critically read the manuscript and made helpful suggestions. Acknowledgement is due to the International Association of Sedimentologists (IAS) for awarding a research grant to NS. This work is based on part of NS's PhD research that was supported by the European Social Fund. Additional financial support is from CoRI and MIUR grants to RN.

\section{References}

Accarie, H., Renard, M., Deconinck, J.F., Beaudoin, B., Fleury, J.J., 1989. Géochimie des carbonates ( $\mathrm{Mn}, \mathrm{Sr}$ ) et minéralogie des argiles de calcaires pélagiques sénoniens. Relations avec les variations eustatiques (massif de la Maiella, Abruzzes, Italie). C.R. Acad. Sci., Paris 309, 1679-1685.

Accarie, H., Renard, M., Jorgensen, N.O., 1993. Le manganèse dans les carbonates pélagiques: un outil d'intérêt stratigraphique et paléogéographique (le Sénonien d'Italie, de Tunisie et du Danemark). C.R. Acad. Sci., Paris 316, 1-8.

Al-Suwaidi, A.H., Angelozzi, G.N., Baudin, F., Damborenea, S.E., Hesselbo, S.P., Jenkyns, H.C., Mañcenido, M.O., Riccardi, A.C., 2010. First record of the Early Toarcian Oceanic Anoxic Event from the Southern Hemisphere, Neuquén Basin, Argentina. J. Geol. Soc. London 167, 633-636.

Arthur, M.A., Sageman, B.B., 1994. Marine black shales: a review of depositional mechanisms and significance of ancient deposits. Ann. Rev. Earth Planet. Sci. 22, 499-551.

Beerling, D.J., Lomas, M.R., Gröcke, D.R., 2002. On the nature of methane gas-hydrate dissociation during the Toarcian and Aptian oceanic anoxic event. Am. J. Sci. 302, 28-49.

Bellanca, A., Masetti, D., Neri, R., 1997. Rare earth elements in limestone/marlstone couplets from the Albian-Cenomanian Cismon section (Venetian region, northern Italy): assessing REE sensitivity to environmental changes. Chem. Geol. 141, 141-152. 
Bellanca, A., Masetti, D., Neri, R., Venezia, F., 1999. Geochemical and sedimentological evidence of productivity cycles recorded in Toarcian black shales from the Belluno Basin, Southern Alps, Northern Italy. J. Sed. Res. 69, 466-476.

Berner, R.A., 1970. Sedimentary pyrite formation. Am. J. Sci. 268, 1-23.

Bernoulli, D., Jenkyns, H.C., 1974. Alpine, Mediterranean and Central Atlantic Mesozoic facies in relation to the early evolution of the Tethys. In: Dott, R.H., Shaver, R.H. (Eds.), Modern and Ancient Geosynclinal Sedimentation, a Symposium: Spec. Publ. Soc. Econ. Paleont. Miner., 19, pp. 129-160.

Bernoulli, D., Jenkyns, H.C., 2009. Ancient oceans and continental margins of the Alpine-Mediterranean Tethys: deciphering clues from Mesozoic pelagic sediments and ophiolites. Sedimentology 56, 149-190

Bosellini, A., Masetti, D., Sarti, M., 1981. A Jurassic 'Tongue of the Ocean' infilled with oolitic sands: the Belluno Trough, Venetian Alps, Italy. Mar. Geol. 44, 59-95.

Breit, G.N., Wanty, R.B., 1991. Vanadium accumulation in carbonaceous rocks: a review of geochemical controls during deposition and diagenesis. Chem. Geol. 91, 83-97.

Buser, S., 1996. Geology of western Slovenia and its paleogeographic evolution. In Drobne, K., Goričan, Š., Kotnik, B. (Eds.), The role of Impact Processes in the Geological and Biological Evolution of Planet Earth, pp. 111-123. International Workshop, ZRC SAZU, Ljubljana.

Butler, I.B., Rickard, D., 2000. Framboidal pyrite formation via the oxidation of iron (II) monosulfide by hydrogen sulphide. Geochim. Cosmochim. Acta 64, 2665-2672.

Claps, M., Erba, E., Masetti, D., Melchiorri, F., 1995. Milankovitch-type cycles recorded in Toarcian black shales from the Belluno Trough (Southern Alps Italy). Mem. Sci. Geol. Padova 47, 179-188.

Corbin, J.C., 1994. Evolution géochimique du Jurassique du Sud-Est de la France: influence des variations du niveau marin et de la tectonique: Mém. Sc. Terre Univ. P. et M. Curie, Paris, 94-12, p. 177.

Corbin, J.C., Person, A., Iatzoura, A., Ferré, B., Renard, M., 2000. Manganese in pelagic carbonates: indication of major Tectonic events during the geodynamic evolution of a passive continental margin (the Jurassic European margin of the TethysLigurian Sea). Palaeogeogr. Palaeoclimatol. Palaeoecol. 156, 123-138.

Cousin, M., 1981. Les rapports Alpes-Dinarides: les confines de l'Italie et de la Yougoslavie. Soc. Géol. du Nord Publ. 5, 1042.

Cronan, D.S., Galácz, A., Mindszenty, A., Moorby, A., Polgári, M., 1991. Tethyan ferromanganese oxides deposits from Jurassic rocks in Hungary. J. Geol. Soc London 148, 655-668.

Danielson, A., Möller, P., Dulski, P., 1992. The europium anomalies in banded iron formations and the thermal history of the oceanic crust. Chem. Geol. 97, 89-100.

de Baar, H.J.W., Bacon, M.P., Brewer, P.G., Bruland, K.W., 1985. Rare earth elements in the Pacific and Atlantic oceans. Geochim. Cosmochim. Acta 49, 2561-2571.

de Baar, H.J.W., German, C.R., Elderfield, H., van Gaans, P., 1988. Rare earth element distribution in anoxic waters of the Carioca Trench. Geochim. Cosmochim. Acta 52, 1203-1219.

de Graciansky, P.C., Jacquin, T., Hesselbo, S.P., 1998. The Ligurian cycle: an overview of Lower Jurassic 2nd-order transgressive/regressive facies cycles in western Europe. In: de Graciansky, P.C. Hardenbol, J. Jacquin, T., Vail, P.R. (Eds.), Mesozoic and Cenozoic Sequence Stratigraphy of European Basins: SEPM Spec. Publ., 60, pp. 467-479.

Dean, W.E., Arthur, M.A., 1989. Iron-sulfur-carbon relationships in organic-carbon-rich sequences: Cretaceous Western Interior Seaway. Am. J. Sci. 289, 708-743.

Dekov, V.M., Marchig, V., Rajta, I., Uzonyi, I., 2003. Fe-Mn micronodules born in the metalliferous sediments of two spreading centres: the East Pacific Rise and MidAtlantic Ridge. Mar. Geol. 199, 101-121.

Di Stefano, P., Mindszenty, A., 2000. Fe-Mn-encrusted "Kamenitza" and associated features in the Jurassic of Monte Kumeta (Sicily): subaerial and/or submarine dissolution? Sed. Geol. 132, 37-68.

Di Stefano, P., Galacz, A., Mallarino, G., Mindszenty, A., Vörös, A., 2002. Birth and early evolution of a Jurassic escarpment: Monte Kumeta, western Sicily. Facies 46, 273-298.

Dolenec, T., Lojen, S., Ramovš, A., 2001. The Permian-Triassic boundary in Western Slovenia (Idrijca Valley section): magnetostratigraphy, stable isotopes, and elemental variations. Chem. Geol. 175, 175-190.

Douville, E., Bienvenu, P., Charlou, J.L., Donval, J.P., Fouquet, Y., Appriou, P., Gamo, T. 1999. Yttrium and rare earth elements in fluids from deep-sea hydrotherma systems. Geochim. Cosmochim. Acta 63 (5), 627-643.

Dubinin, A.V., 2004. Geochemistry of rare earth elements in the ocean. Lithol. Miner Resour. 39 (4), 289-307.

Ebli, O., Vetö, I., Lobitzer, H., Sajgò, C., Demény, A., Hetényi, M., 1998. Primary productivity and early diagenesis in the Toarcian Tethys on the example of the Mnrich black shales of the Sachrang Formation, Northern Calcareous Alps. Org. Geochem. 29, 1635-1647.

Force, E.R., Cannon, W.F., 1988. Depositional model for shallow-marine manganese deposits around black shale basins. Econ. Geol. 83, 93-117.

Frakes, L.A., Bolton, B.R., 1984. Origin of manganese giants: sea level change and anoxic-oxic history. Geology 12, 83-86.

Franzini, M., Leoni, L., Saitta, M., 1975. Revisione di una metodologia analitica per fluorescenza X basata sulla correzione completa degli effetti di matrice. Rend. Soc. Ital. Mineral. Petrol. 21, 99-108.

Froelich, P.N., Klinkhammer, G.P., Bender, M.L., Luedtke, N., Heath, G.R., Cullen, D., Dauphin, P., Hammond, P., Hartman, B., Maynard, V., 1979. Early oxidation of organic matter in pelagic sediments of the eastern equatorial Atlantic: suboxic diagenesis. Geochim. Cosmochim. Acta 43 (7), 1075-1090.

German, C.R., Elderfield, H., 1990. Application of the Ce anomaly as a paleoredox indicator: the ground rules. Paleoceanography 5, 823-833.

Germann, K., 1972. Verbreitung und Entstehung manganreicher Gesteine im Jura der Nördlichen Kalkalpen. Tschermaks Min. Pet. Mitt 17, 123-150.
Glasby, G.P., Stüben, D., Jeschke, G., Stoffers, P., Garbe-Schönberg, C.D., 1997. A model for the formation of hydrothermal manganese crusts from the Pitcairn Island hotspot. Geochim. Cosmochim. Acta 61, 4583-4597.

Goričan, Š., Šmuc, A., Baumgartner, P.O., 2003. Toarcian Radiolaria from Mt. Mangart (Slovenian-Italian border) and their paleoecological implications. Mar. Micropaleontol. 49, 275-301.

Hallam, A., 1981. A revised sea-level curve for the Early Jurassic. J. Geol. Soc. London $138,735-741$.

Hallam, A., 1998. A re-evaluation of Jurassic eustasy in the light of new data and the revised Exxon curve. In: Wilgus, C.K., Hastings, B.S., Posamentier, H., Van Wagoner, J., Ross, C.A., Kendall, G.St.C (Eds.), Sea-level change: an integrated approach: SEPM Spec. Publ., 42, pp. 261-273.

Haq, B.U., Hardenbol, J., Vail, P., 1987. Chronology of fluctuating sea levels since the Triassic. Science 235, 1156-1167.

Hardenbol, J., Thierry, J., Farley, M.B., Jacquin, T., de Graciansky, P.C., Vail, P.R., 1998 Mesozoic and Cenozoic sequence chronostratigraphic framework in European basins. In: de Graciansky, P.C., Hardenbol, J., Jacquin, T., Vail, P.R. (Eds.), Mesozoic and Cenozoic Sequence Stratigraphy of European Basins: SEPM Spec. Publ., 60, pp. 3-13.

Haskin, M.A., Haskin, L.A., 1966. Rare earths in European shales: a redetermination. Science 154, 507-509.

Hatch, J.R., Leventhal, J.S., 1992. Relationship between inferred redox potential of the depositional environment and geochemistry of the Upper Pennsylvanian (Missourian) Stark Shale Member of the Dennis Limestone, Wabaunsee County, Kansas, U.S.A. Chem. Geol. 99, 65-82.

Hein, J.R., Koschinsky, A., Halbach, P., Manheim, F.T., Bau, M., Kang, J.K., Lubick, N., 1997. Iron and manganese oxide mineralization in the Pacific. In: Nicholson, K., Hein, J.R., Bühn, B., Desgupta, S. (Eds.), Manganese Mineralization: Geochemistry and Mineralogy of Terrestrial and Marine Deposits: Geol. Soc. London Spec. Publ. 119 , pp. $123-138$.

Heiser, U., Neumann, T., Scholten, J., Stüben, D., 2001. Recycling of manganese from anoxic sediments in stagnant basins by seawater inflow: a study of surface sediments from the Gotland Basin, Baltic Sea. Mar. Geol. 177, 151-166.

Hermoso, M., Minoletti, F., Le Callonnec, L., Jenkyns, H.C., Hesselbo, S.P., Rickaby, R.E.M., Renard, M. de Rafelis, M., Emmanuel, L., 2009a. Global and local forcing of Early Toarcian seawater chemistry: a comparative study of different paleoceanographic settings (Paris and Lusitanian basins). Paleoceanography 24, PA4208. doi:10.1029/ 2009PA001764.

Hermoso, M., Renard, M., Hesselbo, S.P., 2009b. Expression of the Early Toarcian negative carbon-isotope excursion in separated carbonate microfractions (Jurassic, Paris Basin). Earth Planet. Sci. Lett. 277, 194-203.

Hesselbo, S.P., Gröcke, D.R., Jenkyns, H.C., Bjerrum, C.J., Farrimond, P., Morgans Bell, H.S Green, O.R., 2000. Massive dissociation of gas hydrate during a Jurassic oceanic anoxic event. Nature 406, 392-395.

Hesselbo, S.P., Jenkyns, H.C., Duarte, L.V., Oliveira, L.C.V., 2007. Carbon-isotope record of the Early Jurassic (Toarcian) Oceanic Anoxic Event from fossil wood and marine carbonate (Lusitanian Basin, Portugal). Earth Planet. Sci. Lett. 253, 455-470.

Holser, W.T., 1997. Evaluation of the application of rare earth elements to paleoceanography. Palaeogeogr. Palaeoclimatol. Palaeoecol. 132, 309-323.

Huckriede, H., Meischner, D., 1996. Origin and environment of manganese-rich sediments within black-shale basin. Geochim. Cosmochim. Acta 60, 1399-1413.

Hülsemann, J., 1966. On the routine analysis of carbonates in unconsolidated sediments. J. Sediment. Petrol. 36, 622-625.

Jach, R., Dudek, T., 2005. Origin of a Toarcian manganese carbonate/silicate deposit from the Krížna unit, Tatra Mountains, Poland. Chem. Geol. 224, 136-152.

Jenkyns, H.C., 1970. Fossil manganese nodules from the west Sicilian Jurassic. Eclog. Geol. Helv. 63, 741-774.

Jenkyns, H.C., 1971. The genesis of condensed sequences in the Tethyan Jurassic. Lethaia $4,327-352$.

Jenkyns, H.C., 1977. Fossil nodules. In: Glasby, G.P. (Ed.), Marine Manganese Deposits Elsevier, Amsterdam, pp. 87-108.

Jenkyns, H.C., 1988. The the Early Toarcian (Jurassic) anoxic event: stratigraphic sedimentary and geochemical evidence. Am. J. Sci. 288, 101-151.

Jenkyns, H.C., 2003. Evidence for rapid climate change in the Mesozoic-Paleogene greenhouse world. Philos. Trans. R. Soc. London, A 361, 1885-1916.

Jenkyns, H.C., 2010. Geochemistry of oceanic anoxic events. Geochem. Geophys. Geosyst 11, 003004 doi:10.1029/2009GC002788.

Jenkyns, H.C., Clayton, C.J., 1986. Black shales and carbon isotopes in pelagic sediments from the Tethyan Lower Jurassic. Sedimentology 33, 87-106.

Jenkyns, H.C., Clayton, C.J., 1997. Lower Jurassic epicontinental carbonates and mudstones from England and Wales: chemostratigraphic signals and the early Toarcian anoxic event. Sedimentology 44, 687-706.

Jenkyns, H.C., Sarti, M., Masetti, D., Howarth, M.K., 1985. Ammonites and stratigraphy of Lower Jurassic black shales and pelagic limestones from the Belluno Trough, Southern Alps, Italy. Eclog. Geol. Helv. 78, 299-311.

Jenkyns, H.C., Géczy, B., Marshall, J.D., 1991. Jurassic manganese carbonates of central Europe and the Early Toarcian anoxic event. J. Geol. 99, 137-149.

Jenkyns, H.C., Gröcke, D.R., Hesselbo, S.P., 2001. Nitrogen isotope evidence for wate mass denitrification during the early Toarcian (Jurassic) oceanic anoxic event Paleoceanography 16, 593-603.

Jenkyns, H.C., Jones, C.E., Gröcke, D.R., Hesselbo, S.P., Parkinson, D.N. 2002. Chemostratigraphy of the Jurassic System: applications, limitations and implications for palaeoceanography. J. Geol. Soc. London 159, 351-378.

Kemp, D.B., Coe, A.L., Cohen, A.S., Schwark, L., 2005. Astronomical pacing of methane release in the early Jurassic period. Nature 437, 396-399. 
Krajewski, K.P., Lefeld, J., Łącka, B., 2001. Early diagenetic processes in the formation of carbonate-hosted Mn ore deposit (Lower Jurassic, Tatra Mountains) as indicated from its carbon isotopic record. Bull. Pol. Acad. Sci. Earth Sci. 49, 13-29.

Krieger, P., 1930. Note on an X-ray diffraction study of the series calcite-rhodochrosite. Am. Mineral. 15, 23-29.

Lewan, M.D., 1984. Factors controlling the proportionality of vanadium to nickel in crude oils. Geochim. Cosmochim. Acta 48, 2231-2238.

Lewan, M.D., Maynard, J.B., 1982. Factors controlling enrichment of vanadium and nickel in the bitumen of organic sedimentary rocks. Geochim. Cosmochim. Acta 46, 2547-2560.

Li, Y.H., 1981. Ultimate removal mechanisms of elements from the ocean. Geochim. Cosmochim. Acta 45, 1659-1664.

Liu, Y.G., Miah, M.R.U., Schmitt, R.A., 1988. Cerium: a chemical tracer for paleo-oceanic redox conditions. Geochim. Cosmochim. Acta 52,1361-1371.

Lottermoser, B.G., 1992. Rare earth elements and hydrothermal ore formation processes. Ore Geol. Rev. 7, 25-41.

MacLeod, K.G., Irving, A.J., 1996. Correlation of cerium anomalies with indicators of paleoenvironment. J. Sediment. Res. 66, 948-988.

Manceau, A., Drits, V.A., Silverster, E., Bartoli, C., Lanson, B., 1997. Structural mechanism of $\mathrm{Co}^{2+}$ oxidation by the phyllomanganate buserite. Am. Mineral. 82, 1150-1175.

Masetti, D., Bianchin, G., 1987. Geologia del Gruppo della Schiara (Dolomiti Bellunesi). Suo inquadramento nella evoluzione giurassica del margine orientale della Piattaforma di Trento. Mem. Sci. Geol. Padova 34, 187-212.

Michard, A., 1989. Rare earth element systematics in hydrothermal fluids. Geochim. Cosmochim. Acta 53, 745-750.

Michard, A., Albarède, F., 1986. The REE content of some hydrothermal fluids. Chem. Geol. 55, 51-60.

Milodowski, A.E., Zalasiewicz, J.A., 1991. Redistribution of rare earth elements during diagenesis of turbidite/hemipelagite mudrock sequences of Llandovery age from central Wales. In: Morton, A.C., Todd, S.P., Haughton, P.D.W. (Eds.), Developments in Sedimentary Provenance. Geol. Soc. London Spec. Publ. 57, 101-124.

Murray, R.W., Buchholtz ten Brink, M.R., Jones, D.L., Gerlach, D.C., Russ III, G.P, 1990. Rare earth elements as indicators of different marine depositional environments in chert and shale. Geology 18, 268-271.

Murray, R.W., Buchholtz ten Brink, M.R., Gerlach, D.C., Russ III, G.P., Jones, D.L., 1991. Rare earth, major, and trace elements in chert from the Franciscan Complex and Monterey Group, California: assessing REE sources to fine-grained marine sediments. Geochim. Cosmochim. Acta 55, 1875-1895.

Murray, R.W., Buchholtz ten Brink, M.R., Gerlach, D.C., Russ III, G.P., Jones, D.L., 1992. Interoceanic variation in the rare earth, major, and trace element depositional chemistry of chert: perspectives gained from the DSDP and ODP record. Geochim. Cosmochim. Acta 56, 1897-1913.

Neumann, T., Heiser, U., Leosson, M.A., Kersten, M., 2002. Early diagenetic processes during Mn-carbonate formation: evidence from the isotopic composition of authigenic Ca-rhodochrosites of the Baltic Sea. Geochim. Cosmochim. Acta 66, 867-879.

Okita, P.M., Shanks III, W.C., 1992. Origin of stratiform sediment-hosted manganese carbonate ore deposits: example from Molango, Mexico, and Taojiang, China. Chem. Geol. 99, 139-164.

Okita, P.M., Maynard, J.B., Spiker, E.C., Force, E.R., 1988. Isotopic evidence for organic matter oxidation by manganese reduction in the formation of stratiform manganese carbonate ore. Geochim. Cosmochim. Acta 52, 2679-2685.

Piper, D.Z., 1974. Rare earth elements in the sedimentary cycle: a summary. Chem. Geol. $14,285-304$.

Placer, L., 1999. Contribution to the macrotectonic subdivision of the border region between Southern Alps and External Dinarides. Geologija 41, 223-255.

Polgári, M., Okita, P.M., Hein, J.R., 1991. Stable isotope evidence for the origin of the Úrkút manganese ore deposit, Hungary. J. Sed. Petrol. 61, 384-393.

Polgári, M., Szabó-Drubina, M., Szabó, Z., 2004. Theoretical model for Jurassic manganese mineralization in Central Europe, Úrkút, Hungary. Bull. Geosci. 79, 53-61.

Pratt, L.M., Force, E.R., Pomerol, B., 1991. Coupled manganese and carbon-isotopic events in marine carbonates at the Cenomanian-Turonian boundary. J. Sed. Petrol. 61 (3), 370-383.

Raiswell, R., Berner, R.A., 1985. Pyrite formation in euxinic and semi-euxinic sediments. Am. J. Sci. 285, 710-724
Rantitsch, G., Melcher, F., Meisel, T., Rainer, T., 2003. Rare earth, major and trace elements in Jurassic manganese shales of the Northern Calcareous Alps: hydrothermal versus hydrogenous origin of stratiform manganese deposits. Mineral. Petrol. 77, 109-127.

Renard, M., Letolle, R., 1983. Essai d'interprétation du rôle de la profondeur de dépôt dans la répartition des teneurs en manganèse et dans l'évolution du rapport isotopique du carbone des carbonates pélagiques: influence de l'oxygénation du milieu. C.R. Acad. Sci., Paris 296, 1737-1740.

Röhl, H.J., Schmid-Röhl, A., Oschmann, W., Frimmel, A., Schwark, L., 2001. The Posidonia Shale (Lower Toarcian) of SW-Germany: An oxygen-depleted ecosystem controlled by sea level and palaeoclimate. Palaeogeogr. Palaeoclimatol. Palaeoecol. $165,27-52$.

Rona, P.A., Klinkhammer, G., Nelsen, T.A., Trefry, J.H., Elderfield, H., 1986. Black smokers, massive sulfides, and vent biota at the Mid-Atlantic Ridge. Nature 321, 33-37.

Sabatino, N., Neri, R., Bellanca, A., Jenkyns, H.C., Baudin, F., Parisi, G., Masetti, D., 2009 Carbon-isotope records of the Early Jurassic (Toarcian) Oceanic Anoxic Event from the Valdorbia (Umbria-Marche Apennines) and Monte Mangart (Julian Alps) sections: palaeoceanographic and stratigraphic implications. Sedimentology 56 1307-1328.

Sass, E., Bein, A., Almogi-Labin, A., 1991. Oxygen-isotope composition of diagenetic calcite in organic-rich rocks: evidence for ${ }^{18} \mathrm{O}$ depletion in marine anaerobic pore water. Geology 19, 839-842.

Schijf, J., de Baar, H.J.W., Millero, F.J., 1995. Vertical distributions and speciation of dissolved rare earth elements in the anoxic brines of Bannock Basin, eastern Mediterranean Sea. Geochim. Cosmochim. Acta 59, 3285-3299.

Schouten, S., van Kaam-Peters, H.M.E., Rijpstra, W.I.C., Schoell, M., Damsté, J.S.S., 2000 Effects of an oceanic anoxic event on the stable carbon isotopic composition of Early Toarcian carbon. Am. J. Sci. 300, 1-22.

Šmuc, A., Goričan, Š., 2005. Jurassic sedimentary evolution of a carbonate platform into a deep-water basin, Mt. Mangart (Slovenian-Italian border). Riv. Ital. Paleont. Stratigr. 111, 45-70.

Stumm, W., Morgan, J.J., 1981. Aquatic Chemistry, 2nd edn. Wiley, New York.

Suan, G., Mattioli, E., Pittet, B., Mailliot, S., Lécuyer, C., 2008. Evidence for major environmental perturbation prior to and during the Toarcian (Early Jurassic) Oceanic Anoxic Event from the Lustanian Basin, Portugal. Paleoceanography 23 PA1202. doi:10.1029/2007PA001459.

Takahashi, Y., Manceau, A., Geoffroy, N., Marcus, M.A., Usui, A., 2007. Chemical and structural control of the partitioning of $\mathrm{Co}, \mathrm{Ce}$ and $\mathrm{Pb}$ in marine ferromanganese oxides. Geochim. Cosmochim. Acta 71, 984-1008.

Takematsu, N., Sato, Y., Okabe, S., 1989. Factors controlling the chemical composition of marine manganese nodules and crusts: a review and synthesis. Mar. Chem. 26, 41-56.

Taylor, K.G., Macquaker, J.H.S., 2000. Early diagenetic pyrite morphology in a mudstone-dominated succession: the Lower Jurassic Cleveland Ironstone Formation, eastern England. Sediment. Geol. 131, 77-86.

Usui, A., Bau, M., Yamazaki, T., 1997. Manganese microchimneys buried in the Central Pacific pelagic sediments: evidence of intraplate water circulation? Mar. Geol. 141, 269-285.

Vetö, I., Demény, A., Hertelendi, E., Hetényi, M., 1997. Estimation of primary productivity in the Toarcian Tethys. A novel approach based on TOC, reduced sulphur and manganese contents. Palaeogeogr. Palaeoclimatol. Palaeoecol. 132, 355-371.

Wilkin, R.T., Barnes, H.L., 1997. Formation processes of framboidal pyrite. Geochim. Cosmochim. Acta 61, 323-339.

Wilkin, R.T., Barnes, H.L., Brantley, S.L., 1996. The size distribution of framboidal pyrite in modern sediments: an indicator of redox conditions. Geochim. Cosmochim. Acta 60, 3897-3912.

Winterer, E.L., Bosellini, A., 1981. Subsidence and sedimentation on Jurassic Passive Continental Margin, Southern Alps, Italy. AAPG Bull. 65, 394-421.

Woodfine, R.G., Jenkyns, H.C., Sarti, M., Baroncini, F., Violante, C., 2008. The response of two Tethyan carbonate platforms to the early Toarcian oceanic anoxic event: environmental change and differential subsidence. Sedimentology 55, 1011-1028.

Wright, J., Schrader, H., Holser, W.T., 1987. Paleoredox variations in ancient oceans recorded by rare earth elements in fossil apatite. Geochim. Cosmochim. Acta 51, 631-644. 